\title{
Fucoxanthin, a Marine-Derived Carotenoid from Brown Seaweeds and Microalgae: A Promising Bioactive Compound for Cancer Therapy
}

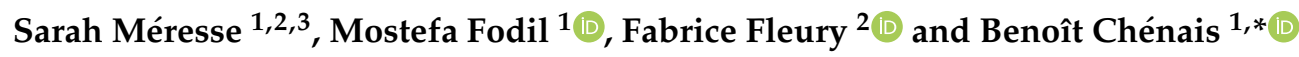 \\ 1 EA 2160 Mer Molécules Santé, Le Mans Université, F-72085 Le Mans, France; \\ Sarah.Meresse@cnrs-orleans.fr (S.M.); Mostefa.Fodil@univ-lemans.fr (M.F.) \\ 2 UMR 6286 CNRS Unité Fonctionnalité et Ingénierie des Protéines, Université de Nantes, \\ F-44000 Nantes, France; Fabrice.Fleury@univ-nantes.fr \\ 3 UMR 7355 CNRS Immunologie et Neurogénétique Expérimentales et Moléculaires, F-45071 Orléans, France \\ * Correspondence: bchenais@univ-lemans.fr; Tel.: +33-243-833-251
}

Received: 23 October 2020; Accepted: 2 December 2020; Published: 4 December 2020

\begin{abstract}
Fucoxanthin is a well-known carotenoid of the xanthophyll family, mainly produced by marine organisms such as the macroalgae of the fucus genus or microalgae such as Phaeodactylum tricornutum. Fucoxanthin has antioxidant and anti-inflammatory properties but also several anticancer effects. Fucoxanthin induces cell growth arrest, apoptosis, and/or autophagy in several cancer cell lines as well as in animal models of cancer. Fucoxanthin treatment leads to the inhibition of metastasis-related migration, invasion, epithelial-mesenchymal transition, and angiogenesis. Fucoxanthin also affects the DNA repair pathways, which could be involved in the resistance phenotype of tumor cells. Moreover, combined treatments of fucoxanthin, or its metabolite fucoxanthinol, with usual anticancer treatments can support conventional therapeutic strategies by reducing drug resistance. This review focuses on the current knowledge of fucoxanthin with its potential anticancer properties, showing that fucoxanthin could be a promising compound for cancer therapy by acting on most of the classical hallmarks of tumor cells.
\end{abstract}

Keywords: angiogenesis; apoptosis; cancer; cell growth arrest; DNA repair; EMT; fucoxanthin; inflammation; invasion; migration

\section{Introduction}

Carotenoids are colored and natural pigments widely distributed in nature. They include more than 1100 molecules [1], divided into two classes: xanthophylls, which contain oxygen, and carotenes, which are pure hydrocarbons. In photosynthetic organisms such as plants and algae, carotenoids have two major roles: they absorb energy for photosynthesis and also protect chlorophyll from photodamage [2]. At a structural level, xanthophyll pigments are close to each other, they share a long carbon chain containing one or more oxygen atoms, which differentiates them from carotenes. These carotenoids pigments are well-known for their antioxidant and anti-inflammatory properties [3-5], but they also display some potential anticancer effects.

First isolated in 1914 by Willstätter and Page, fucoxanthin (Figure 1) is an orange-colored xanthophyll pigment derived from brown algae and microalgae [6-8]. It is found in high content in taxons such as Phaeophyceae, Haptophyta, Bacillariophyceae, and Chrysophyceae, and to a lesser extent in Rhodophyta, Raphidophyceae, and Dinophyta [9]. Fucoxanthin is one of the most abundant carotenoid pigments, which contributes to more than $10 \%$ of the estimated total carotenoid production in nature, particularly in the marine environment [10].

Popular sources of fucoxanthin include macroalgae such as Laminaria japonica, Eisenia bicyclis, and the well-known brown seaweed Wakame (Undaria pinnatifida), as well as diatoms microalgae 
such as Phaeodactylum tricornutum [11] (Table 1). Fucoxanthin exhibit several biological activities that are beneficial to human health including antioxidant, anti-inflammatory, anti-obesity, anti-diabetic, anti-angiogenic, and anticancer properties [12-17].

Table 1. Source and concentration of fucoxanthin in different algal samples.

\begin{tabular}{|c|c|c|c|c|}
\hline & Class & Species & $\begin{array}{l}\text { Fucoxanthin } \\
\text { Yield (mg/g) }\end{array}$ & References \\
\hline \multirow{28}{*}{ Macroalgae } & \multirow{28}{*}{ Phaeophyceae } & Alaria crassifolia & $0.04^{\mathrm{a}}$ & [18] \\
\hline & & Cladosiphon okamuranus & - & {$[19,20]$} \\
\hline & & Cystoseira hakodatensis & $1.53^{\mathrm{a}}$ & [18] \\
\hline & & Dictyota coriacea & $6.42^{\mathrm{a}}$ & [21] \\
\hline & & Eisenia bicyclis & $0.26^{\mathrm{b}}-0.41^{\mathrm{a}}$ & {$[18,22]$} \\
\hline & & Fucus evanescens C. agardh & $0.017^{\mathrm{a}}$ & [23] \\
\hline & & Fucus vesiculus & $0.26-1.24$ & [24] \\
\hline & & Ishige okamurae & - & [25] \\
\hline & & Kjellmaniella crassifolia & $0.197^{\mathrm{a}}$ & [18] \\
\hline & & Laminaria japonica & $0.03^{b}-0.19^{b}$ & {$[26,27]$} \\
\hline & & Myagropsis myagroides & $9.01^{\mathrm{a}}$ & [21] \\
\hline & & Padina tetrastromatica & $0.18^{\mathrm{b}}$ & [28] \\
\hline & & Petalonia binghamiae & $0.43^{b}-0.58^{b}$ & [29] \\
\hline & & Saccharina japonica & - & [30] \\
\hline & & Sargassum fusiformis & $0.01^{\mathrm{a}}-0.02^{\mathrm{b}}$ & {$[26,27]$} \\
\hline & & Sargassum binderi & $0.73^{a}$ & [31] \\
\hline & & Sargassum duplicatum & $1.01^{\mathrm{a}}$ & {$[31]$} \\
\hline & & Sargassum hemiphyllum & - & [16] \\
\hline & & Sargassum horneri & $1.10^{\mathrm{a}}$ & [18] \\
\hline & & Sargassum plagyophyllum & $0.71^{\mathrm{a}}$ & [31] \\
\hline & & Sargassum polycystum & $0.31^{\mathrm{a}}$ & [32] \\
\hline & & Sargassum siliquastrum & $0.75^{\mathrm{a}}$ & {$[33,34]$} \\
\hline & & Sargassum siliquosum & $1.41^{\mathrm{a}}$ & {$[32]$} \\
\hline & & Scytosiphon lomentaria & $0.24^{\mathrm{b}}-0.56^{\mathrm{b}}$ & [29] \\
\hline & & Sphaerotrichia divaricata & $0.11^{\mathrm{a}}-1.48^{\mathrm{a}}$ & [35] \\
\hline & & Turbinaria decurrens & $0.65^{\mathrm{a}}$ & [36] \\
\hline & & Turbinaria turbinata & $0.59^{a}$ & [31] \\
\hline & & Undaria pinnatifida & $0.11^{b}-1.09^{a}$ & {$[26,27]$} \\
\hline
\end{tabular}


Table 1. Cont.

\begin{tabular}{|c|c|c|c|c|}
\hline & Class & Species & $\begin{array}{l}\text { Fucoxanthin } \\
\text { Yield (mg/g) }\end{array}$ & References \\
\hline \multirow{20}{*}{ Microalgae } & \multirow{4}{*}{ Bacillariophyceae } & Cyclotella sp. & $0.7^{\mathrm{a}}-2.3^{\mathrm{a}}$ & [37] \\
\hline & & Nitzschia sp. & $4.92^{\mathrm{a}}-5.5^{\mathrm{a}}$ & {$[22,37]$} \\
\hline & & Paralia longispina & $1.4^{\mathrm{a}}$ & [37] \\
\hline & & Phaeodactylum tricornutum & $8.55^{\mathrm{a}}-24.2^{\mathrm{a}}$ & {$[22,37]$} \\
\hline & Coccolithophyceae & Prymnesium parvum & $7.91^{\mathrm{a}}$ & [38] \\
\hline & Chromulinaceae & Chromulina ochromonoides & $1.32^{\mathrm{a}}$ & [39] \\
\hline & \multirow{2}{*}{ Chrysophyceae } & Ochromonas sp. & $0.41^{\mathrm{a}}$ & [39] \\
\hline & & Ochromonas danica & $3.16^{\mathrm{a}}$ & [38] \\
\hline & \multirow{3}{*}{ Coscinodiscophyceae } & Chaetoceros calcitrans & $5.25^{\mathrm{a}}$ & [40] \\
\hline & & Ochromonas gracilis & $2.24^{\mathrm{a}}$ & [22] \\
\hline & & Odontella aurita & $21.67^{\mathrm{a}}$ & [41] \\
\hline & Mediophyceae & Conticribra weissflogii ND8 & $6^{\mathrm{a}}$ & [42] \\
\hline & \multirow{3}{*}{ Prymnesiophyceae } & Isochrysis sp. & $17^{\mathrm{a}}$ & [43] \\
\hline & & Isochrysis affinis galbana & $18.23^{a}$ & [22] \\
\hline & & Isochrysis galbana & $6.04^{\mathrm{a}}$ & [22] \\
\hline & Raphidophyceae & Olisthodiscus luteus & $0.08^{\mathrm{a}}$ & [39] \\
\hline & \multirow{3}{*}{ Synurophyceae } & Synura petersenii & $0.02^{\mathrm{a}}$ & [39] \\
\hline & & Mallomonas sp. SBV13 & $26.6^{\mathrm{a}}$ & [37] \\
\hline & & Poterioochromonas malhamensis & $0.6^{\mathrm{a}}$ & [39] \\
\hline & Zygnematophyceae & Cylindrotheca closterium & $5.23^{\mathrm{a}}$ & {$[44]$} \\
\hline
\end{tabular}

${ }^{a}$ data obtained from dry biomass; ${ }^{b}$ data obtained from fresh biomass.

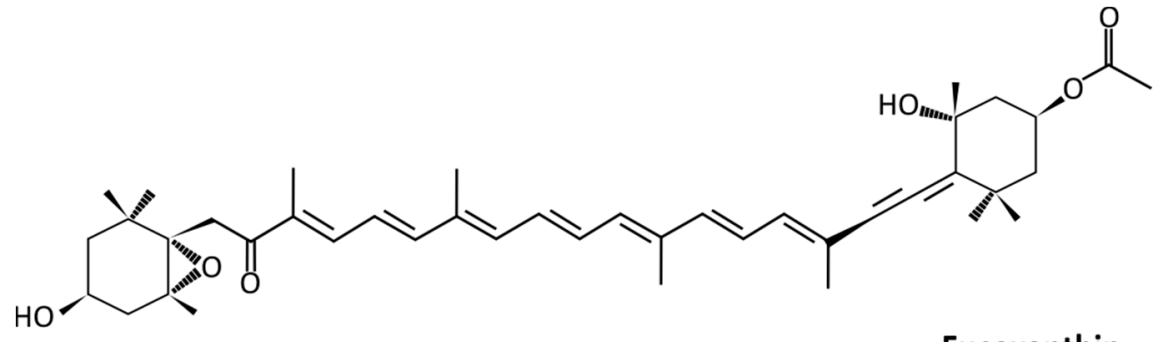

Fucoxanthin

Figure 1. Structure of fucoxanthin ( $3^{\prime}$-acetoxy-5,6-epoxy-3, $5^{\prime}$-dihydroxy- $6^{\prime}, 7^{\prime}$-didehyro-5, 6,7,8, $5^{\prime}, 6^{\prime}$ hexahydro- $\beta$, $\beta$-carotene-8-one; $\left.\mathrm{C}_{42} \mathrm{H}_{58} \mathrm{O}_{6} ; 658.91 \mathrm{~g} / \mathrm{mol}\right)$.

\section{Absorption and Metabolites of Fucoxanthin}

Being hydrophobic, carotenoids are absorbed in the intestine following the same path as dietary fats. Fucoxanthin has an allenic bond, a polyene chain, an acetyl, and a $\beta, \gamma$-epoxy ketone group (Figure 1). There is no symmetry between the two six-membered ring derivatives bound by the polyene chain: one has an allenic bond, the second has a $\beta, \gamma$-epoxy ketone group. In vivo, the bioactive forms of fucoxanthin are fucoxanthinol and/or amarouciaxanthin. When ingested, fucoxanthin is mainly metabolized to fucoxanthinol in the gastrointestinal tract by digestive enzymes such as lipase and cholesterol esterase by hydrolysis [45], and it is further converted to amarouciaxanthin A in the liver [46] (Figure 2a). Research on the possible effects of amarouciaxanthin A remains insufficient 
in the context of cancer. Nonetheless, beneficial health effects of fucoxanthin and fucoxanthinol are well described.

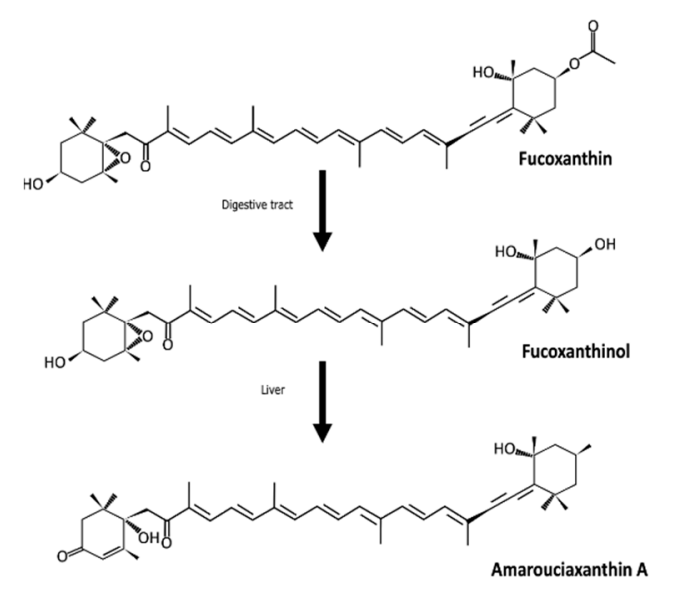

(a)

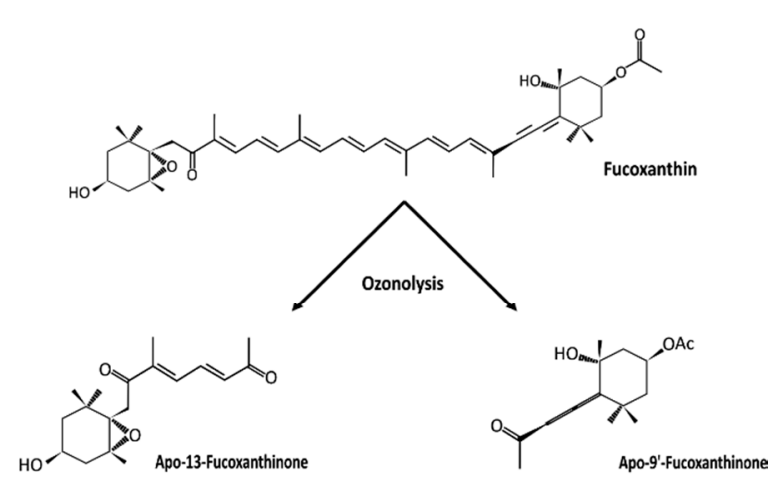

(b)

Figure 2. Natural (a) and synthetic (b) metabolites of fucoxanthin (adapted from Komba et al., 2018 [47]).

Two other synthetic metabolites could be obtained by chemical degradation (ozonolysis) of fucoxanthin apo-9'-fucoxanthinone [48] and apo-13-fucoxanthinone [49] (Figure 2b). Ozonolysis cleaved the polyene chain of fucoxanthin into two types of cyclohexyl derivatives, the first one with a $\beta, \gamma$-epoxy ketone group and the second one with an allenic bond. Caco- 2 cells (human colorectal carcinoma) were treated with compounds resulting from fucoxanthin degradation to determine the correlation between structure and activity. From this study, the complete structure of fucoxanthin appears not indispensable for its antiproliferative effect, which could be achieved by a partial structure of the molecule $[29,47]$.

Given the high safety of fucoxanthin and its metabolites, and their significant bioactivities and pharmacological effects, fucoxanthin has the potential to become a promising nutritional ingredient and a potential medicinal constituent for human health [50]. Here, we will discuss fucoxanthin as a potential treatment and/or preventive agent of cancer development and aggressiveness.

\section{Antiproliferative Effects of Fucoxanthin through Cell Cycle Arrest in Cancer Cells}

The antiproliferative effect of fucoxanthin has been reported for several cancer cell lines (Table 2), including human leukemia cell lines, K562 and TK6 [51], adult T-cell leukemia [52], B-cell malignancies, including Burkitt's lymphoma, Hodgkin's lymphoma, and Epstein-Barr virus-immortalized B cells [19], primary effusion lymphoma (PEL), a rare type of non-Hodgkin's lymphoma [53], human bladder cancer T24 cell line [54], melanoma cell lines (B16F10 cells) [55], human gastric adenocarcinoma MGC-803 cells [56], colon adenocarcinoma cell lines WiDr and HCT116 [57], LNCap and DU145 prostate cancer cells [58-60], human neuroblastoma GOTO cell line [61], human hepatocarcinoma HepG2 cell line [59,60,62,63], SK-Hep-1 human hepatoma cells [64], cervical cancer cells HeLa [65], and osteosarcoma cell lines [20]. The inhibition of cell proliferation by fucoxanthin is due to cell growth arrest at G0/G1 or G1 phase of the cell cycle $[19,20,52-55,57-62,64,65]$. 
Table 2. In vitro effects of fucoxanthin on cancer and non-cancer cells.

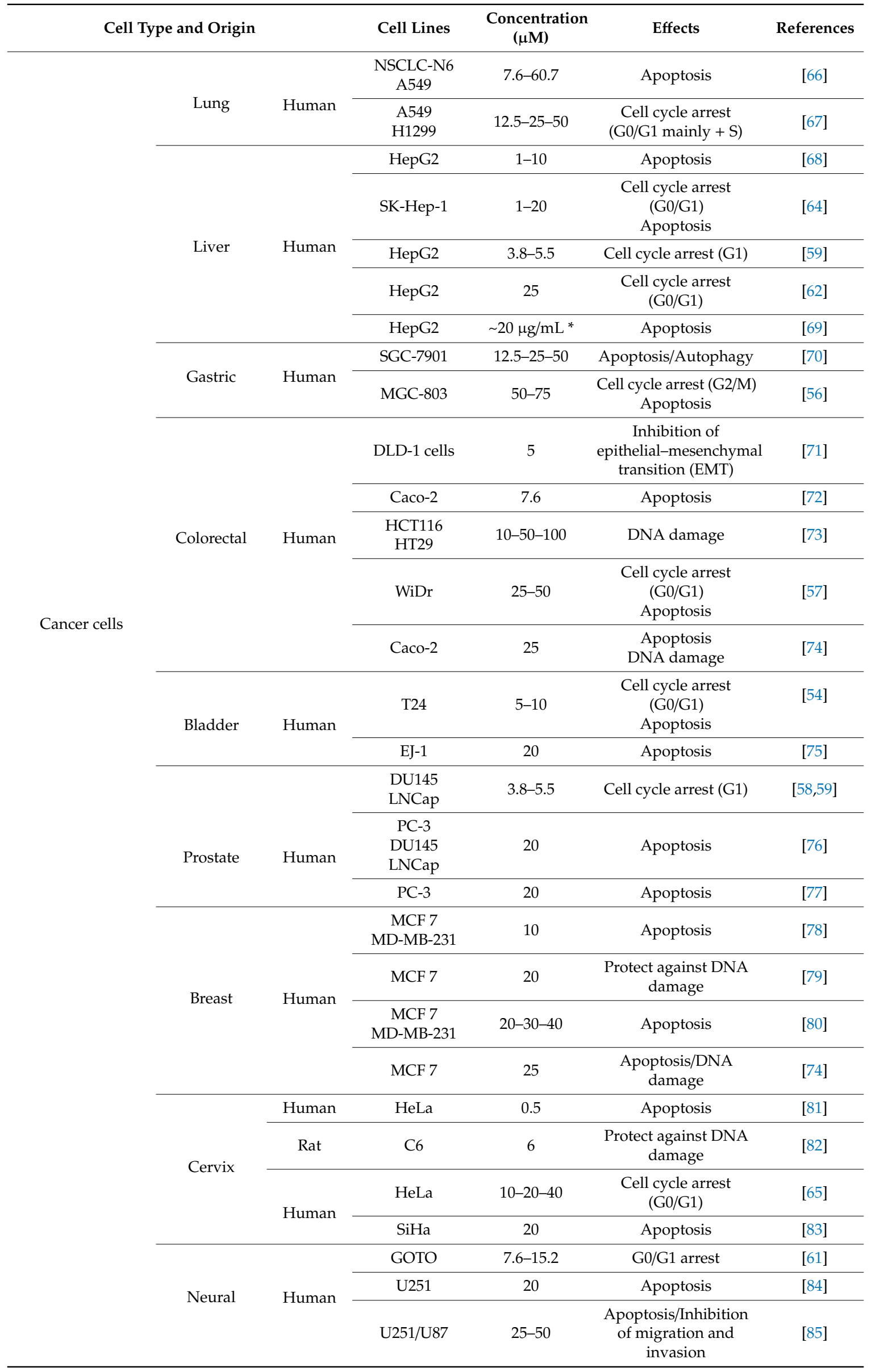


Table 2. Cont.

\begin{tabular}{|c|c|c|c|c|c|c|}
\hline \multicolumn{3}{|c|}{ Cell Type and Origin } & Cell Lines & $\begin{array}{l}\text { Concentration } \\
(\mu \mathrm{M})\end{array}$ & Effects & References \\
\hline \multirow{2}{*}{\multicolumn{2}{|c|}{ Lymphoma }} & \multirow[t]{2}{*}{ Human } & $\begin{array}{c}\text { Raji } \\
\text { Daudi } \\
\text { Ramos } \\
\text { BJAB } \\
\text { L428 } \\
\text { KM-H2 } \\
\text { HDLM-2 } \\
\text { L540 }\end{array}$ & $2.5-5$ & $\begin{array}{l}\text { Cell cycle arrest } \\
\text { (G1; at lower } \\
\text { concentration) } \\
\text { Apoptosis (at } \\
\text { higher } \\
\text { concentration) }\end{array}$ & [19] \\
\hline & & & $\begin{array}{c}\text { HHV-8 } \\
\text { infected } \\
\text { BCBL-1 and } \\
\text { TY-1 }\end{array}$ & $5-10$ & $\begin{array}{c}\text { Cell cycle arrest } \\
\text { (G1) }\end{array}$ & [53] \\
\hline & \multirow{5}{*}{ Leukemia } & \multirow{5}{*}{ Human } & HL-60 & $12.5-25$ & $\begin{array}{c}\text { Apoptosis/DNA } \\
\text { Damage }\end{array}$ & [74] \\
\hline & & & HL-60 & 10 & Apoptosis & [86] \\
\hline & & & $\begin{array}{l}\text { K562 } \\
\text { TK6 }\end{array}$ & 10 & Antiproliferative & [51] \\
\hline & & & $\begin{array}{l}\text { MT-2/MT-4 } \\
\text { HUT-102 } \\
\text { ED-40515(-) }\end{array}$ & 10 & $\begin{array}{c}\text { Cell cycle arrest } \\
\text { (G1) } \\
\text { Apoptosis }\end{array}$ & [52] \\
\hline & & & HL-60 & 15 & Apoptosis & [25] \\
\hline & \multirow[t]{2}{*}{ Melanoma } & \multirow[t]{2}{*}{ Mouse } & B16-F10 & 30 & $\begin{array}{c}\text { Inhibition of } \\
\text { invasion and } \\
\text { migration } \\
\text { Growth inhibition }\end{array}$ & [30] \\
\hline & & & B16-F10 & 50-100-200 & $\begin{array}{c}\text { Cell cycle arrest } \\
\text { (G0/G1) } \\
\text { Apoptosis }\end{array}$ & [55] \\
\hline & Sarcoma & Human & Saos 2 & 20 & Apoptosis & [20] \\
\hline \multirow{4}{*}{$\begin{array}{l}\text { Non-cancer } \\
\quad \text { cells }\end{array}$} & $\begin{array}{l}\text { Umbilical vein } \\
\text { endothelial cells }\end{array}$ & \multirow{4}{*}{ Human } & HUVEC & $1-5$ & Anti-angiogenic & [14] \\
\hline & Keratinocytes & & $\mathrm{HaCaT}$ & $5^{* *}$ & Anti-inflammatory & [15] \\
\hline & $\begin{array}{l}\text { Umbilical vein } \\
\text { endothelial cells }\end{array}$ & & HUVEC & $\begin{array}{c}2.5-5-10 \\
-25-50-100\end{array}$ & Anti-angiogenic & [87] \\
\hline & $\begin{array}{l}\text { Lymphatic } \\
\text { endothelial cells }\end{array}$ & & HLEC & $25-50-100$ & Anti-angiogenic & [88] \\
\hline
\end{tabular}

* this concentration corresponds to an extract enriched with fucoxanthin and not pure fucoxanthin (cf. [69]). ${ }^{* *}$ in combination with rosmarinic acid.

In bladder and colon cancer cells, this arrest in the cell cycle is mediated by the upregulation of p21WAF1/Cip1, a cyclin-dependent kinase (CDK)-inhibitory protein [54,57]. The molecular mechanism of cell cycle arrest also involves the downregulation of cyclin D1 and CDK4 complex in B cell malignancies, bladder cancer, melanoma, and HepG2 hepatocarcinoma cell lines [19,54,55,62]. In bladder cancer cells, a decrease of CDK-2 and cyclin E was also observed [54], whereas a decrease of cyclin D2 appears in B cell malignancies and melanoma cells [19,55], and a decreased expression of CDK4, CDK6, and cyclin E could be found in adult T-cell Leukemia [52]. In the HepG2 cell line, Das et al. observed a downregulation of the kinase activity of cyclin D and CDK4 complex, responsible for the phosphorylation of Ser780 of retinoblastoma protein (pRb) [62]. Also, Kim et al. showed a clear lowering of the protein expression of phosphorylated $\mathrm{pRb}$ (phospho-pRb), cyclin D1, cyclin D2, and CDK4. They also observed an upregulation of the proteins p27Kip1 and p15INK4B in B16-F10 cells (melanoma) treated with fucoxanthin [55]. In contrast, in colon cancer cell lines, Das et al. have shown that G0/G1 phase arrest was mediated through the increased phosphorylation of $\mathrm{pRB}$ and upregulation of p21WAF1/Cip1 but not p27Kip1, and without changes in the protein levels of the D-types of cyclin 
and CDK4 [57]. In addition, the study of Satomi et al., using prostate cancer cell lines, suggested that GADD45A and Jun-N-terminal kinase (JNK) might be involved in fucoxanthin-induced G1 cell cycle arrest [58]. Curiously, only one study has reported a fucoxanthin-induced cell cycle arrest in G2/M phase, which was related to a decreased expression of cyclin B1 and survivin in human gastric adenocarcinoma MGC-803 cells [56].

The antiproliferative effect of fucoxanthin was confirmed in vivo by studies showing tumor growth arrest in the presence of fucoxanthin with several types of cancer (Table 3). For example, Mei et al. showed in vivo anti-lung cancer effect of fucoxanthin, and Kim et al. showed that the growth of tumor mass in B16F10 cells-implanted Balb/c mice has been significantly inhibited by the intraperitoneal administration of fucoxanthin [55,67].

Finally, the molecular mechanism that supports the observed G0/G1 phase arrest appears dependent on the cancer cell type but mainly involves cyclin D1 and/or D2 and CDK4 downregulation (Figure 3). However, cyclin E and CDK2 or CDK6 could also be involved in some cell types.

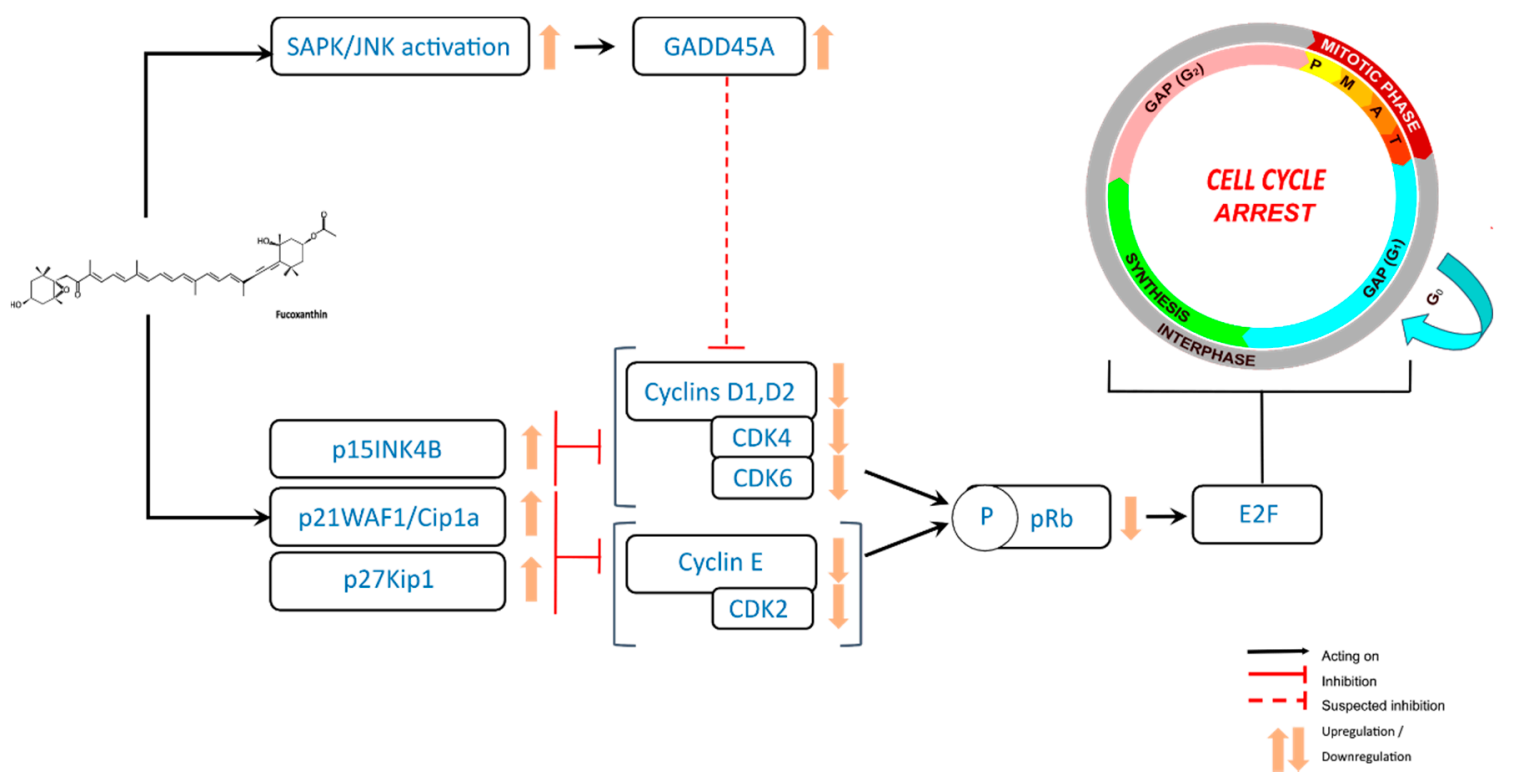

Figure 3. Antiproliferative effects of fucoxanthin through cell cycle arrest in cancer cells. 
Table 3. Effects of fucoxanthin and fucoxanthinol effects on in vivo cancer models (mice).

\begin{tabular}{|c|c|c|c|c|c|c|}
\hline & Contex & & Dose & Administration & Effects & References \\
\hline \multirow{14}{*}{ Fucoxanthin } & Lung & Engrafted with A549 cells & $5-15-50 \mathrm{mg} / \mathrm{kg}$ & Oral & Necrosis & [67] \\
\hline & Liver & Carcinogenesis model & $0.001 \%$ in drinking water & Oral & $\begin{array}{l}\text { Inhibition of } \\
\text { carcinogenesis }\end{array}$ & [89] \\
\hline & \multirow{2}{*}{ Duodenal } & Carcinogenesis models & $0.005 \%$ in drinking water & Oral & $\begin{array}{l}\text { Inhibition of } \\
\text { carcinogenesis }\end{array}$ & [90] \\
\hline & & Carcinogenesis models & $0.005 \%$ in drinking water & Oral & $\begin{array}{l}\text { Inhibition of } \\
\text { carcinogenesis }\end{array}$ & [91] \\
\hline & \multirow[b]{2}{*}{ Colorectal } & Carcinogenesis models & $30 \mathrm{mg} / \mathrm{kg}$ & Injection (stomach) & Anoikis & [92] \\
\hline & & Carcinogenesis models & $0.01 \%$ in drinking water & Oral & $\begin{array}{l}\text { Inhibition of } \\
\text { carcinogenesis }\end{array}$ & [93] \\
\hline & Breast & $\begin{array}{l}\text { Engrafted with } \\
\text { MDA-MB-231 cells }\end{array}$ & $\begin{array}{l}100 \text { and } 500 \mu \mathrm{mol} / \mathrm{L} ; \\
100 \mu \mathrm{L} / \mathrm{mouse}\end{array}$ & Injection & Anti-angiogenic & {$[88]$} \\
\hline & Cervix & Engrafted with HeLa cells & 10 and $20 \mathrm{mg} / \mathrm{kg}$ & Oral & Growth inhibition & [81] \\
\hline & Lymphoma & Engrafted with B16-F10 & $150 \mathrm{mg} / \mathrm{kg}$ & Oral & Growth inhibition & [53] \\
\hline & \multirow{2}{*}{ Melanoma } & Engrafted with B16-F10 & $0.1 \mathrm{mg} / \mathrm{mouse}$ & $\begin{array}{c}\text { Intra-peritoneal } \\
\text { injection }\end{array}$ & Anti-metastasis & {$[30]$} \\
\hline & & Carcinogenesis models & $200 \mathrm{nM} /$ painting & $\begin{array}{c}\text { Topical application } \\
\text { (skin painting) }\end{array}$ & $\begin{array}{c}\text { Inhibition of } \\
\text { carcinogenesis }\end{array}$ & [91] \\
\hline & \multirow[b]{2}{*}{ Sarcoma } & Engrafted with S180 cells & 50 and $100 \mathrm{mg} / \mathrm{kg}$ & Oral & Apoptosis & [94] \\
\hline & & Engrafted with LM8 cells & $200 \mathrm{mg} / \mathrm{kg}$ & Oral & Growth inhibition & [20] \\
\hline & Glioblastoma & Engrafted with U87 cells & $200 \mathrm{mg} / \mathrm{kg}$ & Oral & Growth inhibition & [85] \\
\hline \multirow[t]{2}{*}{ Fucoxanthinol } & Lymphoma & $\begin{array}{c}\text { Engrafted with HUT-102 } \\
\text { cells }\end{array}$ & $200 \mathrm{mg} / \mathrm{kg}$ & Oral & Growth inhibition & [52] \\
\hline & Sarcoma & Engrafted with LM8 cells & $200 \mathrm{mg} / \mathrm{kg}$ & Oral & Growth inhibition & [20] \\
\hline
\end{tabular}




\section{Induction of Apoptosis and Autophagy in Cancer Cells}

Autophagy and apoptosis are mechanisms involved in the development of a variety of cancers. Fucoxanthin has been highlighted to induce autophagy and apoptosis in cellular cell lines including HeLa, SGC-7901, and human cervical cancer $[65,70,83]$ (Table 2). Anoikis is useful to maintain homeostasis in normal conditions. Anoikis is the name given to induction of apoptosis in cells upon loss of attachment to the extracellular matrix and cellular neighborhood [95]. Cancer cells are resistant to anoikis, favoring metastasis and new tumor growth $[95,96]$. In order to include fucoxanthin in a potential therapeutic strategy, some pathways have been studied and identified to be involved in those cytotoxic effects.

\subsection{Apoptosis}

Fucoxanthin inhibited the growth of U251 human glioma cells in a time- and dose-dependent manner by induction of apoptosis with poly-ADP-ribose polymerase (PARP) cleavage and caspase activation [84]. Furthermore, fucoxanthin treatment of glioma cells caused disturbance of mitogen-activated protein kinases (MAPKs) and phosphoinositide-3 kinase (PI3K)-Akt pathways, in a time-dependent manner. This was highlighted by the activation by phosphorylation of Thr183-JNK, Thr180-p38, and Thr202 of extracellular signal-regulated kinase (ERK) and, in contrast, the inactivation of Akt by phosphorylation of Ser473 [84]. However, the inhibition of reactive oxygen species (ROS) by the antioxidant glutathione counteracts fucoxanthin effects, including the alteration of MAPKs and PI3K-Akt signaling, DNA damage, and cytotoxicity and cell apoptosis. This indicates that ROS production acts as an early apoptotic event and is involved in the fucoxanthin-triggered anticancer mechanism [84].

Results consistent with the data described above were obtained using the human U87 glioma cell line [85]. In the human hepatocarcinoma HepG2 cell line, apoptosis induction by fucoxanthin was correlated to a decreased expression of genes coding antioxidant enzymes superoxide dismutase (SOD1, SOD2) and catalase (CAT) and downregulation of signaling pathways (AKT, JNK, ERK1/2) [69]. The involvement of ROS in fucoxanthin-induced apoptosis was also reported for HL-60 leukemia and fucoxanthin-induced cytotoxicity, and apoptosis was suppressed by the ROS scavenger $\mathrm{N}$-acetylcysteine (NAC) [25]. In HL-60 cells, fucoxanthin induced the cleavage of caspase-3, caspase-7, and PARP, and a decrease of the apoptosis inhibitor Bcl-xL. Moreover, the pre-treatment of cells with NAC prevented these effects of fucoxanthin [25]. In accordance, fucoxanthin increased the apoptosis in human cervical cancer cells, namely HeLa, SiHa, and CaSki cell lines, by targeting the PI3K/Akt/nuclear factor-kappa B (NF-kB) signaling pathway [83]. Fucoxanthin was also shown to synergize with tumor necrosis factor-related apoptosis-inducing ligand (TRAIL) to induce apoptosis in human cervical cancer cells [83].

Fucoxanthin also induces apoptosis in human EJ-1 and T24 bladder cancer cell lines [54,75]. In T24 cells, fucoxanthin-induced apoptosis was linked to a decrease in the expression level of mortalin, which is a stress regulator and a member of heat shock protein 70 , followed by upregulation of cleaved caspase-3 at a high dose $(40 \mu \mathrm{M})[54]$.

Fucoxanthin induced apoptosis of non-small cell lung cancer by modulating expression of p53, p21, Fas, p53 upregulated modulator of apoptosis (PUMA), Bcl-2, and caspase-3/8 [67]. In the B16F10 human melanoma cell line, fucoxanthin-induced apoptosis was associated with the downregulation of Bcl-xL, leading to the sequential activation of caspase-9, caspase-3, and PARP [55]. If most studies report the activation of caspase-3 as a hallmark of fucoxanthin-induced apoptosis, some discrepancies exist about the pro- and anti-apoptotic proteins. For example, fucoxanthin reduced the expression of Bax and Bcl-2 proteins, but not Bcl-xL, in the prostate cancer cell line PC-3 [77], while decreasing $\mathrm{Bcl}-\mathrm{xL}$ in B16F10 melanoma cells [55]. In contrast, fucoxanthin has no effect on the protein level of Bcl-2, Bcl-xL, or Bax in HL-60 promyelocytic leukemia cells [97]. The decrease of survivin, an apoptosis inhibitory protein, expression was thought to be responsible for the induction of apoptosis by a high dose of fucoxanthin $(75 \mu \mathrm{M})$ in human gastric adenocarcinoma MGC-803 cells [56]. 
Fucoxanthin (Table 2) and more importantly its metabolite fucoxanthinol (Table 4) are able to reduce NF- $\kappa B$ activation and induce apoptosis of the colorectal cancer cell line HCT116, breast cancer cell lines MCF-7 and MDA-MB-231, B-cell malignancies, and primary effusion lymphoma [19,53,78,80,98]. In all these studies, fucoxanthinol was reported to be more potent than its precursor fucoxanthin. This was also observed in the murine macrophages' cell line RAW264.7, where high concentrations of both fucoxanthin and fucoxanthinol $(>10 \mu \mathrm{M})$ induced apoptosis with activation of caspase 3/7 and suppression of the anti-apoptotic proteins, such as Bcl-xL and phospho-Akt.

Table 4. In vitro effects of fucoxanthinol on cancer and non-cancer cells.

\begin{tabular}{|c|c|c|c|c|c|c|}
\hline \multicolumn{3}{|c|}{ Cell Type and Origin } & \multirow{2}{*}{$\begin{array}{c}\text { Cell Lines } \\
\text { DLD-1 } \\
\end{array}$} & \multirow{2}{*}{$\begin{array}{c}\begin{array}{c}\text { Concentration } \\
(\mu \mathbf{M})\end{array} \\
1-5 \\
\end{array}$} & \multirow{2}{*}{$\begin{array}{l}\text { Effects } \\
\text { Anoikis }\end{array}$} & \multirow{2}{*}{$\begin{array}{c}\text { References } \\
{[92]}\end{array}$} \\
\hline & & & & & & \\
\hline & Colorectal & & DLD-1 & 2.5 & $\begin{array}{c}\text { Anoikis } \\
\text { Inhibition of EMT }\end{array}$ & [99] \\
\hline & cancer & Human & HCT116 & 5 & Apoptosis & [98] \\
\hline & & & Caco-2 & $12.5-25$ & $\begin{array}{c}\text { Apoptosis } \\
\text { DNA damage }\end{array}$ & {$[74]$} \\
\hline & & & $\begin{array}{l}\text { CRC HR29 } \\
\text { HCT } 116\end{array}$ & 50 & Inhibition of EMT & [99] \\
\hline & Breast cancer & Human & MCF-7 & $12.5-25$ & $\begin{array}{c}\text { Apoptosis } \\
\text { DNA damage }\end{array}$ & [74] \\
\hline & & & $\begin{array}{c}\text { MCF 7 } \\
\text { MDA-MB-231 }\end{array}$ & $20-30-40$ & Apoptosis & [80] \\
\hline \multirow[t]{6}{*}{ Cancer cells } & \multirow{3}{*}{ Lymphoma } & \multirow{3}{*}{ Human } & $\begin{array}{c}\text { Raji } \\
\text { Daudi } \\
\text { Ramos, } \\
\text { BJAB } \\
\text { L428 } \\
\text { KM-H2 } \\
\text { HDLM-2 } \\
\text { L540 }\end{array}$ & $1.25-2.5$ & $\begin{array}{l}\text { Cell cycle arrest (G1; } \\
\text { at lower } \\
\text { concentration) } \\
\text { Apoptosis (at higher } \\
\text { concentration) }\end{array}$ & [19] \\
\hline & & & $\begin{array}{c}\text { HHV-8 infected } \\
\text { BCBL-1 } \\
\text { TY-1 }\end{array}$ & $2.5-5$ & Cell cycle arrest (G1) & [53] \\
\hline & & & $\begin{array}{c}\text { MT-2 } \\
\text { MT-4 } \\
\text { HUT-102 } \\
\text { ED-40515(-) }\end{array}$ & 5 & $\begin{array}{c}\text { Cell cycle arrest (G1) } \\
\text { Apoptosis }\end{array}$ & [52] \\
\hline & Leukemia & Human & HL-60 & $6.25-12.5$ & $\begin{array}{c}\text { Apoptosis } \\
\text { Antiproliferative } \\
\text { DNA Damage }\end{array}$ & {$[74]$} \\
\hline & \multirow{2}{*}{ Sarcoma } & \multirow{2}{*}{ Human } & \multirow[t]{2}{*}{ Saos 2} & $0.63-1.25$ & $\begin{array}{l}\text { Inhibition of } \\
\text { migration }\end{array}$ & {$[20]$} \\
\hline & & & & $0.05-0.1$ & $\begin{array}{c}\text { Inhibition of } \\
\text { invasion }\end{array}$ & {$[20]$} \\
\hline $\begin{array}{l}\text { Non-cancer } \\
\text { cells }\end{array}$ & - & Rat & Aortic ring & $2.5-5-10-25$ & Anti-angiogenic & [87] \\
\hline
\end{tabular}

Moreover, lower concentrations of fucoxanthin and fucoxanthinol $(1-4 \mu \mathrm{M})$ have a cytoprotective effect, inducing nuclear factor (erythroid-derived 2)-like 2 (NFE2L2/Nrf2) transcription factor and heme oxygenase antioxidant enzyme expression, while a higher concentration activates NFE2L2/Nrf2 and induces apoptosis [100]. In human Saos-2 osteosarcoma cells, fucoxanthin and fucoxanthinol induce apoptosis, at least in part, by inhibiting Akt and activator protein-1 (AP-1) pathways [20]. Apoptosis of fucoxanthinol-treated Saos-2 cells was characterized by a reduced expression of survivin, $X$-linked inhibitor of apoptosis (XIAP), Bcl-2, and Bcl-xL, and associated with activation of caspases-3, 8, and 
9 [20]. A similar pattern was observed in Adult T-cell Leukemia treated by fucoxanthin or fucoxanthinol, which was twice as potent [52]. In addition, fucoxanthinol inhibited the phosphorylation of Akt, phosphoinositide-dependent kinase 1 , and the downstream glycogen synthase kinase $3 \beta$, leading to the downregulation of $\beta$-catenin [20]. In HL-60 leukemia cells, fucoxanthinol also demonstrated a greater pro-apoptotic effect than fucoxanthin, characterized by a decreased level of Bcl-2 protein [74]. Similarly, a decrease of Bcl-2 protein together with increased DNA fragmentation was observed in CaCo-2 colon cancer cells, which was partially inhibited by a caspase inhibitor Z-VAD-fmk [72]. Effects of fucoxanthin on apoptosis are summarized in Figure 4.

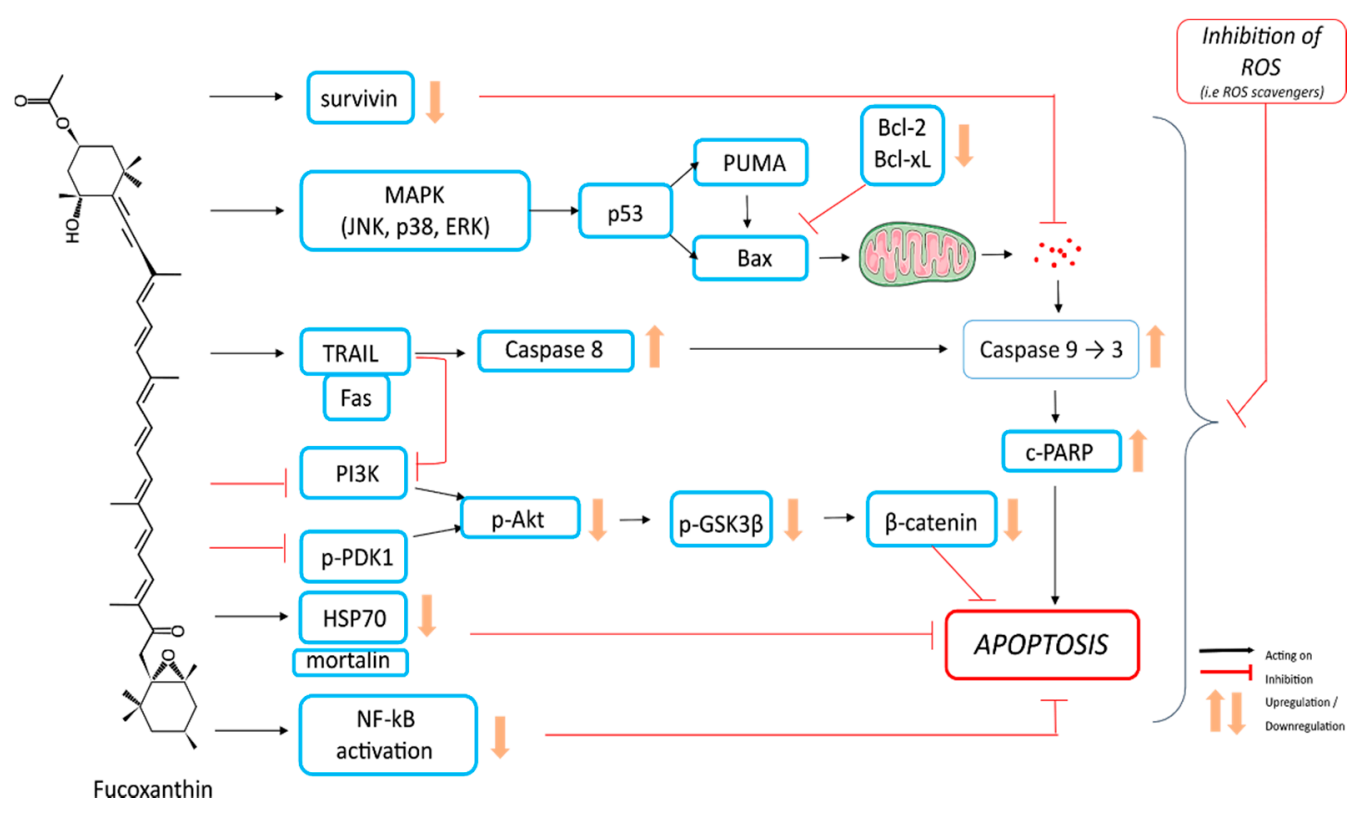

Figure 4. Induction of apoptosis in cancer cells by fucoxanthin.

The in vitro effects of fucoxanthin on cell death are clearly determined and indicate a cytotoxicity, even at low doses, in cancer cell lines. Those effects have also been observed in vivo, in mice bearing xenografted sarcoma 180 (S180). At 50 and $100 \mathrm{mg} / \mathrm{kg}$, fucoxanthin significantly inhibited the growth of sarcoma and induced apoptosis, as demonstrated by the decrease of Bcl-2 expression and a clear increase of cleaved caspase-3 [94]. Moreover, the same authors also reported a clear lowering of survivin, vascular endothelial growth factor (VEGF), epidermal growth factor receptor (EGFR), signal transducer and activator of transcription 3 (STAT3) protein expression, and phosphorylated STAT3 level [94].

\subsection{Anoikis}

A low concentration $(2.5 \mu \mathrm{M})$ of the fucoxanthin metabolite fucoxanthinol induced anoikis, i.e., anchorage-dependent apoptosis, through integrin $\beta 1$ signal suppression in human DLD- 1 colorectal cancer cells [99] (Table 4). The anoikis characteristics were further described in DLD-1 cells as low or null level of integrin $\beta 1$, low or null level of phosphorylated focal adhesion kinase (p-FAK-Tyr397), or low or null level of phosphorylated Paxillin (Tyr31), and with a high level of cleaved caspase-3 [92]. In vitro effects (Figure 5) have been confirmed in vivo using an azoxymethane/dextran sodium sulfate carcinogenic mouse model, showing that fucoxanthin ingestion $(30 \mathrm{mg} / \mathrm{kg}$ body weight) significantly diminished the number and size of polyps compared with untreated control mice and that cells with anoikis features were in colonic crypts significantly increased in fucoxanthin-treated mice [92] (Table 3). 


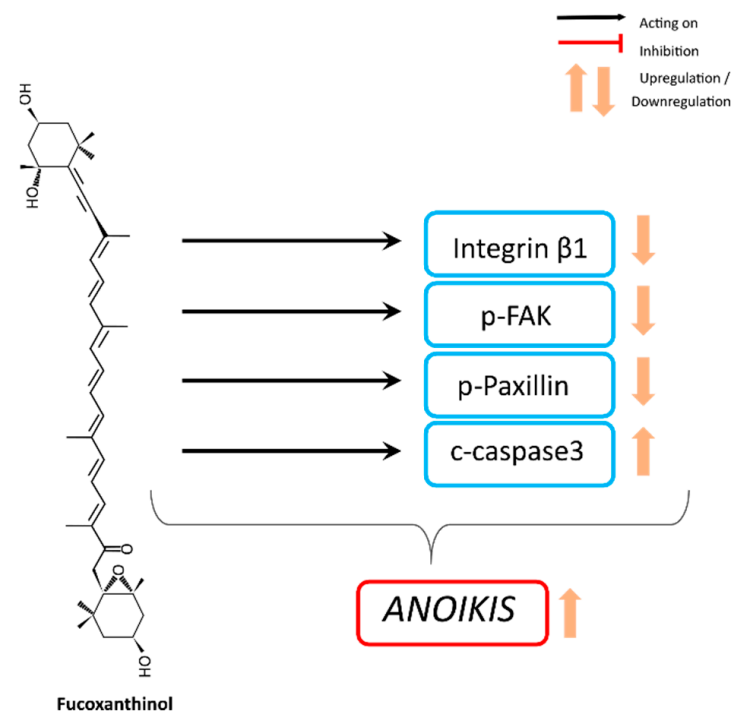

Figure 5. Anoikis induction by fucoxanthinol in cancer cells.

\subsection{Autophagy}

Treatment of HeLa cells with fucoxanthin $(10-80 \mu \mathrm{M})$ increased the protein expression of microtubule-associated protein 1A/1B-light-chain 3 (LC3), an autophagosome marker, and Beclin-1, the initiation factor for autophagosome formation [65]. Furthermore, fucoxanthin decreased the levels of phospho-Akt and its downstream proteins p53, p70S6K, and mechanistic target of rapamycin (mTOR) in a dose-dependent manner, and increased the expression of the so-called "phosphatase and tensin homolog" PTEN protein. This suggests that the cytotoxic effect of fucoxanthin is dependent on autophagy in HeLa cells via inhibition of the Akt/mTOR signaling pathway [65]. In gastric cancer SGC7901 cells, fucoxanthin $(12.5-50 \mu \mathrm{M})$ significantly inhibits the viability of SGC-7901 cells by inducing both autophagy and apoptosis just as effectively, as shown by the downregulation of Bcl-2 and upregulation of Beclin-1, LC3, and cleaved caspase-3. In addition, it appears that fucoxanthin-induced autophagy (Figure 6) occurs prior to apoptosis and may be a promoter of apoptosis [70]. Those two processes are related with each other. Indeed, an increased level of caspase-3 plays a key role in apoptosis.

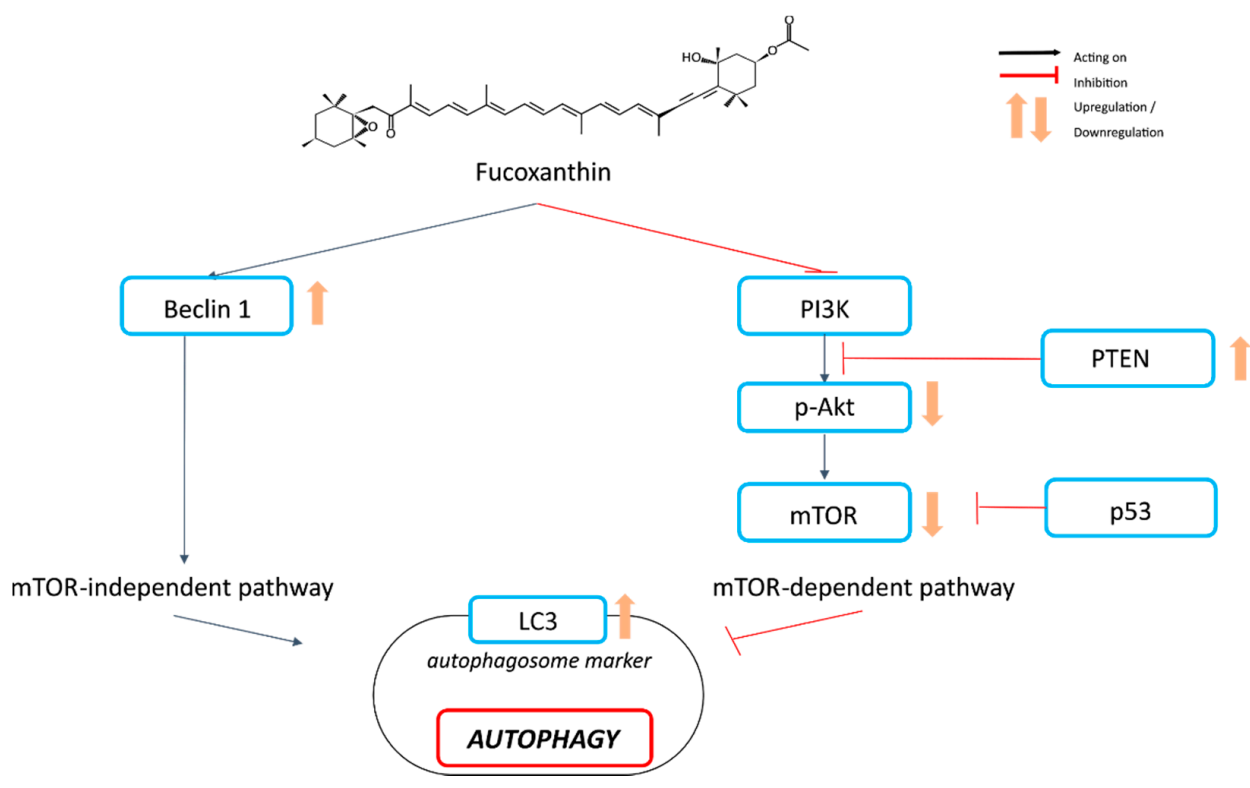

Figure 6. Induction of autophagy in cancer cells by fucoxanthin. 


\section{Involvement in DNA Damages}

Cells are continuously exposed to exogenous and endogenous sources of ROS. The antioxidant properties of fucoxantin limit ROS-induced DNA damage. Thus, in human fibroblast, Heo and Jeon have shown that high concentrations of fucoxanthin (i.e., 5-250 $\mu \mathrm{M}$ ) extracted from the marine algae Sargassum siliquastrum decreased the UV B-induced DNA-damage [33]. In cancer cells, fucoxanthin (at $6 \mu \mathrm{M}$ ) displays a protective effect against UV-induced DNA damage, as well as heavy metal and heat-induced protein misfolding and aggregation of proteins, in rat glioma cells [82] (Table 2). In addition, Fucoxanthin from Sargassum sp. $(20 \mu \mathrm{M})$ also shows some protective effects toward bleomycin-induced DNA damage in MCF-7 breast cancer cells [79].

However, under other experimental conditions, fucoxanthin and its metabolites can lead to inducing DNA damages, which can be used for anticancer therapy. Konishi et al. report an augmentation of DNA damage in HL-60 cells from 12.5 and $6.25 \mu \mathrm{M}$ when cells were treated respectively with fucoxanthin and fucoxanthinol [74] (Table 4). A similar effect was also reported for MCF-7 and Caco-2 cells, and $12.5 \mu \mathrm{M}$ fucoxanthinol significantly enhances DNA damages, while the same effect was obtained with $25 \mu \mathrm{M}$ fucoxanthin [74]. These data confirm that once metabolized by the liver, this biomarine compound becomes more active and beneficial for human health within cancer cells. Interestingly, in colon cancer cell lines HCT116 and HT29, fucoxanthin reduced cell viability and induced DNA damage, but without an apparent effect in normal colon cell line CCD-18Co, except at high concentrations (50 and $100 \mu \mathrm{M})$. This study also reported that fucoxanthin enhanced the cytotoxic effect of 5-fluoro-uracile in colon cancer cells [73].

In human U51 glioma cells, fucoxanthin was shown to time-dependently induce ROS-mediated DNA damage, as evidenced by the activation of "ataxia-telangiectasia mutated" protein (ATM), "ataxia telangiectasia and Rad3-related" protein (ATR), and p53 by phosphorylation of Ser1981-ATM, Ser428-ATR, and Ser15-p53 respectively, as well as by the phosphorylation of Ser139 of histone H2AX [84]. Moreover, in the human hepatocarcinoma cell line HepG2, fucoxanthin pretreatment $(10 \mu \mathrm{M}, 24 \mathrm{~h})$ significantly attenuated cisplatin-induced mRNA expression of DNA repair genes, namely excision repair cross complementation 1 (ERCC1), which is involved in the pathway of DNA nucleotide excision repair and thymidine phosphorylase, a central protein in the pyrimidine nucleoside salvage pathway. Fucoxanthin-modulated mRNA expression leads to improvement of chemotherapeutic efficacy of cisplatin [68]. It is noteworthy that the above-mentioned downregulation of survivin [94] may be linked to the impairment of DNA repair pathways [101,102].

Thus, fucoxanthin may have either a protective or promoting effect with respect to DNA damage depending on the cell types and perhaps the dose used. Further investigations are necessary to identify any impact of fucoxanthin on DNA repair mechanisms.

\section{Inhibition of Metastasis-Related Migration, Invasion and Epithelial-Mesenchymal Transition}

Metastasis is one of the major fundamental mechanisms of invading cancers [103]. The most destructive forms of cancers infiltrate secondary tissues and can escape the immune response. This allows to replace the tumor microenvironment for metastatic colonization by adapting to supportive niches and surviving as latent tumor-initiating cells [104]. Besides, epithelial-mesenchymal transition (EMT) is one of the most important processes controlling metastasis and is hardly regulated by activation of Wnt/ $\beta$-catenin signaling [105]. Many proteins contribute to EMT, such as the mesenchymal structural regulator vimentin, the adhesion/migration marker fibronectin, and the extracellular matrix degrading proteins, i.e., matrix metalloproteinases (MMPs) [106,107].

Fucoxanthin was found to possess strong anticancer and anti-metastatic activities that work irrespective of the p53 status of cancer cells and cause a decrease in hallmark proteins associated with the metastatic spread of cancer cells at doses that were relatively safe to the normal cells [71] (Table 2). The development of osteosarcoma in mice inoculated with osteosarcoma cells was inhibited by a treatment with fucoxanthin [20] (Table 3). Fucoxanthinol, a metabolite of fucoxanthin, inhibited the cell migration and invasion of osteosarcoma cells, and reduced MMP-1 expression and AP-1 signaling [20] 
(Figure 7). In addition, fucoxanthinol significantly suppressed sphere-forming activity, migration, and invasion of human colorectal cancer cell lines HT-29 and HCT116 in a dose-dependent manner [99] (Table 4). Moreover, the expression of $\mathrm{N}$-cadherin and vimentin was suppressed by a treatment with $50 \mu \mathrm{M}$ of fucoxanthinol as well as the activation of integrin signaling linked to EMT inhibition [99]. Fucoxanthin also inhibited the expression and secretion of MMP-9, which plays a critical role in tumor invasion and migration and suppressed invasion of highly metastatic B16-F10 melanoma cells [30], as well as the human glioblastoma cell line U87 [85]. This effect, in glioblastoma cell line U87, is dependent on the p38 MAPK signaling [85]. Furthermore, fucoxanthin decreased the expression of the cell surface glycoprotein CD44 and C-X-C motif chemokine receptor-4 (CXCR4), which are involved in migration, invasion, and adhesion of cancer cells to endothelial cells. Indeed, the adhesion of B16-F10 melanoma cells to the endothelial cells was significantly inhibited by fucoxanthin [30]. Moreover, in vivo metastasis was reduced by fucoxanthin, as shown by a significant reduction of tumor nodules in an experimental lung metastasis in vivo assay [30] and glioblastoma xenografts [85].

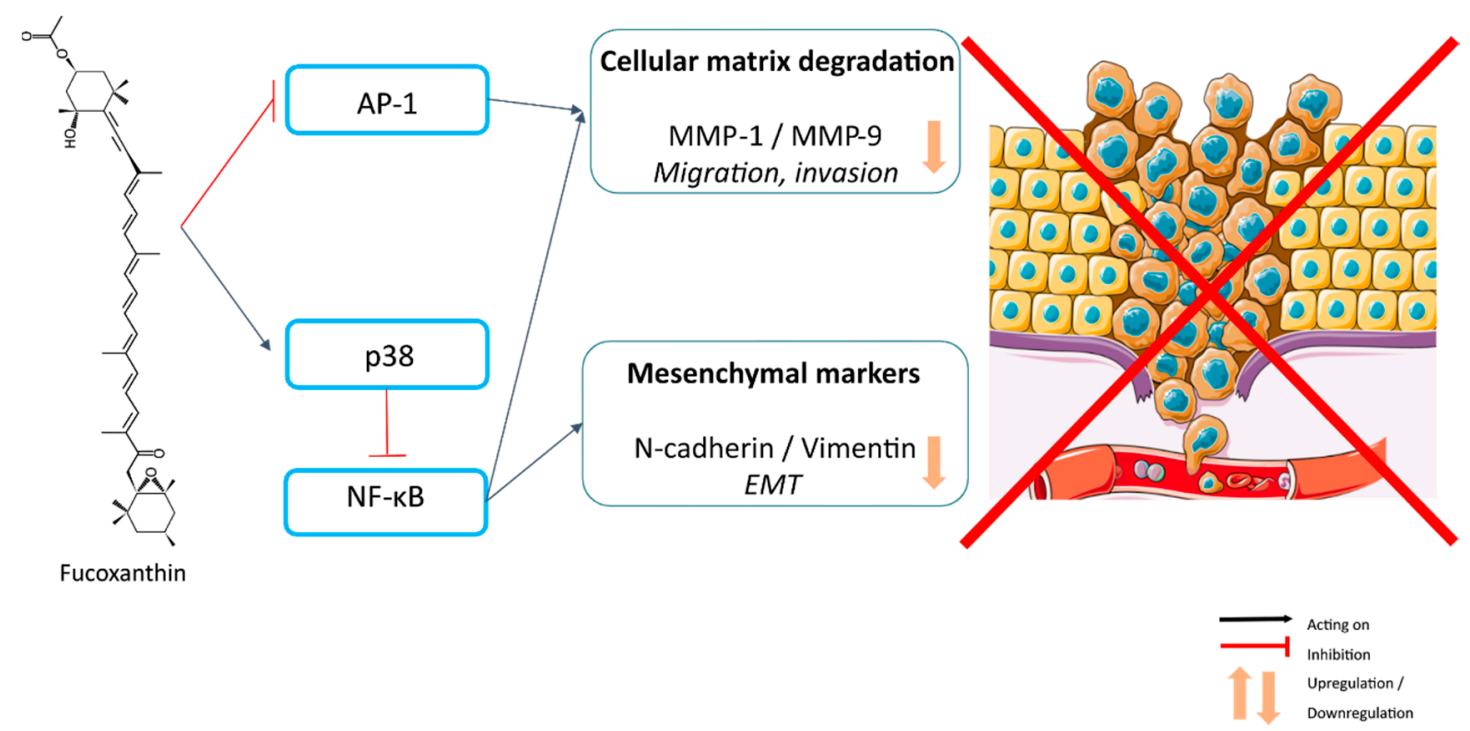

Figure 7. Inhibition of metastasis-related migration, invasion, and epithelial-mesenchymal transition by fucoxanthin.

Taken together, these results show the potential of fucoxanthin in reducing invasion, EMT, and finally, metastasis in some cancer models.

\section{Anti-Angiogenic Effect of Fucoxanthin}

Angiogenesis could be defined as the process of remodeling the primitive network of blood vessels and its growth into a complex network that is regulated by the balance between pro- and anti-angiogenic molecules. During this process, vascular endothelial cells secrete proteases and then migrate through the extracellular matrix, proliferate, and differentiate into new blood vessels [108]. Pathological angiogenesis is involved in many diseases, including rheumatoid arthritis, atherosclerosis, diabetic retinopathy, and cancer [109]. Angiogenesis is mandatory for tumor progression because newly formed blood vessels are needed to supply oxygen and nutrients, which are essential to the growing tumor, and to remove waste products. During angiogenesis, cancer cells secrete various pro-angiogenic factors such as VEGF, platelet-derived growth factor, and fibroblast growth factor 2 (FGF-2) [110]. Also, the metastasis process depends on angiogenesis, as tumor cells migrate from the primary tumor and grow in distant target organs. Few studies highlighted the anti-angiogenic potential of fucoxanthin $[14,87,88]$ (Tables 2 and 3). First, fucoxanthin was shown to inhibit human umbilical vein endothelial cells' (HUVEC) proliferation and tube formation, but without a significant effect on HUVEC chemotaxis [87]. Fucoxanthin (10-20 $\mu \mathrm{M})$ also suppressed the development of blood 
vessel-like structures from CD31-positive cells, and then may suppress the differentiation of endothelial progenitor cells into endothelial cells involving new blood vessel formation. In addition, fucoxanthin and its derivative fucoxanthinol suppressed, in a dose-dependent manner, micro-vessel outgrowth in an ex vivo angiogenesis assay using a rat aortic ring [87] (Table 4). The molecular mechanism of this anti-angiogenic effect of fucoxanthin involves the downregulation of the mRNA level of FGF-2 and its receptor (FGFR-1) as well as their trans-activation factor, EGR-1, as shown in HUVEC treated by fucoxanthin [14]. Moreover, fucoxanthin downregulates the FGF-2-mediated phosphorylation of signaling proteins such as ERK1/2 and Akt, which leads to the repression of endothelial cells' migration as well as their differentiation into tube-like structures on Matrigel ${ }^{\circledR}$ [14]. Another marine-derived compound, siphonaxanthin, structurally close to fucoxanthin, showed similar effects, causing a dose-dependent inhibition on HUVECs proliferation and tube formation (at concentration of 2.5, 10, and $25 \mu \mathrm{M})$. Furthermore, an ex vivo study also indicated the decrease of micro-vessel outgrowth from rat aortic fragments [14].

More recently, Wang et al. used fucoxanthin $(25-100 \mu \mathrm{M})$ extracted from Undaria pinnatifida with human lymphatic endothelial cells (HLEC) and showed inhibition of proliferation, migration, and formation of tube-like structures [88]. In human breast cancer MDA-MB-231 cells, fucoxanthin also suppressed the malignant phenotype and decreased tumor-induced lymphangiogenesis when used in combination with a conditional medium culture system [88]. In vivo, using a MDA-MB-231 nude mouse model of breast cancer, high doses of fucoxanthin $(100-500 \mu \mathrm{M})$ decreased micro-lymphatic vascular density, suggesting that fucoxanthin inhibits tumor-induced lymphangiogenesis in vitro and in vivo. At the cellular level, the mechanism of action of fucoxanthin involves decreased levels of VEGF-C, VEGF receptor-3, NF- $\mathrm{kB}$, p-Akt, and p-PI3K in HLEC [88].

\section{Anti-Inflammatory Effects of Fucoxanthin}

Chronic inflammation has been associated with several stages of tumorigenesis, including cellular transformation, promotion, survival, proliferation, invasion, angiogenesis, and metastasis [111-118]. Cells responsible for cancer-associated inflammation are supposed to be genetically stable and poorly subjected to rapid emergence of drug resistance. Targeting inflammation may be an attractive strategy for cancer prevention and therapy [119].

Pro-inflammatory mediators including interleukins, tumor necrosis factor $\alpha(\mathrm{TNF} \alpha)$, prostaglandin E2, and nitric oxide contribute to the development of a variety of inflammatory diseases [120]. Natural products such as carotenoids have been used in the prevention of oxidative stress due to their antioxidant activities [120]. Despite the fact that the oxidative or anti-oxidative properties of fucoxanthin are discussed and seem to depend on the cellular context, this compound has been studied in an anti-inflammatory context in vivo and in vitro [121,122].

Ishikawa et al. showed, on adult T-cell leukemia-a fatal malignancy of $\mathrm{T}$ lymphocytes caused by human T-cell leukemia virus type 1 (HTLV-1), that fucoxanthin and fucoxanthinol inhibited cell viability and that the metabolite was twice as potent. Interestingly, uninfected cell lines and normal peripheral blood mononuclear cells were resistant to fucoxanthin and fucoxanthinol [52]. In contrast, other carotenoids, astaxanthin and $\beta$-carotene, had mild inhibitory effects on T-cell lines infected by HTLV-1. Otherwise, Lin et al. evaluated the anti-inflammatory effect of $D$. salina carotenoid extract, containing $\alpha$-carotene and $\beta$-carotene on pseudo-rabies virus-infected RAW264.7 cells [123]. They found a downregulation of the expression of pro-inflammatory genes for interleukins (ILs) IL-1 $\beta$, IL-6, and TNF $\alpha$, but also monocyte chemoattractant protein-1 (MCP-1) in a concentration-dependent manner. This was correlated with a decrease of NF-kB activation by Toll-Like receptor-9, dependent on PI3K/Akt activation [123].

A recent study looked at the effects of the combination of fucoxanthin and rosmarinic acid (a bioactive compound from Lamiaceae plants) on inflammasome regulation. This combination improved anti-inflammatory effects from $5 \mu \mathrm{M}$ each. Indeed, the inflammatory response is modulated through downregulation of inflammasome components such as “NOD-like receptor family, pyrin 
domain containing 3" (NLRP3), "apoptosis-associated speck-like protein" (ASC), caspase-1, and interleukins. These results suggest that fucoxanthin, in combination with rosmarinic acid, exerts anti-inflammatory effects by downregulating NRLP3-inflammasome and increasing the NFE2L2/Nrf2 signaling pathway in UVB-exposed HaCaT keratinocytes [15].

\section{Fucoxanthin in Clinical Trials}

Despite proven effects in animal studies, there are few clinical trials with pure algal metabolites, limited to those carried out with kahalalide F and fucoxanthin [124]. Most of the current clinical trials are aimed at confirming the effect of algae consumption, as extracts or fractions, on obesity and diabetes, but, to our knowledge, there are no clinical trials involving fucoxanthin in cancer treatment.

In 2008, Asai et al. detected fucoxanthinol at a concentration of $0.8 \mathrm{nM}$ in plasma of individuals after the daily intake of the brown seaweed wakame (Undaria pinnatifida) containing $6.1 \mathrm{mg}$ fucoxanthin for 1 week [125]. A 16-week clinical trial with 151 obese women using Xanthigen, a dietary supplement composed of brown seaweed extract containing $2.4 \mathrm{mg}$ of fucoxanthin and pomegranate seed oil, was performed by Abidov et al. [126]. The results confirmed a significant weight loss and reduction of abdominal circumference in subjects whose body mass index (BMI) was over $30 \mathrm{~kg} / \mathrm{m}^{2}$ [126].

Otherwise, Hashimoto et al. conducted a study on eighteen human volunteers who received an extract of kombu containing $31 \mathrm{mg}$ of fucoxanthin, administered orally. Peripheral blood was collected before and after the treatment and plasma concentrations of fucoxanthinol were measured by high-pressure liquid chromatography, showing that a maximum concentration of $44.2 \mathrm{nM}$ fucoxanthinol was obtained after $4 \mathrm{~h}$. By contrast, the hepatic metabolite of fucoxanthinol, Amarouciaxanthin A, was not present in the volunteers' plasma [127]. In the same context, Mikami et al. developed a simple and reproducible protocol for quantification of fucoxanthinol in human serum using liquid chromatography coupled with tandem mass spectrometry, which has a high sensitivity and a wide dynamic range. Using capsules of fucoxanthin, prepared by mixing edible brown seaweed (Sargassum horneri) oil and medium-chain triglyceride oil, it was confirmed that fucoxanthinol is a major metabolite of fucoxanthin present in human blood. In addition, although fucoxanthin supplementation does not affect visceral fat areas, it may decrease the level of glycated hemoglobin $(\mathrm{HbA} 1 \mathrm{c})$ in individuals carrying the thrifty allele of uncoupling protein-1 (UCP1-3826A/G) [128].

In 2013, Ren et al. investigated whether fucoxanthin or fucoidan (a polysulfated polysaccharide found in various species of brown seaweed), exhibited anti-thrombotic effects [129]. They prepared three types of capsules from the alga Laminaria japonica, containing $1 \mathrm{mg}$ fucoxanthin, $400 \mathrm{mg}$ fucoidan, and both, and administered it to 24 volunteers for 5 weeks. The dose of fucoidan or fucoidan + fucoxanthin significantly shortened the lysis time of the thrombus, as measured by a global thrombosis test in the blood, but fucoxanthin did not. Examining the mechanism, dietary fucoidan increased the production of $\mathrm{H}_{2} \mathrm{O}_{2}$ and the secretion of prostacyclin (PGI2), a potent inhibitor of platelet aggregation, while fucoidan was below the limit of detection in blood.

Recently, Hitoe and colleagues conducted a clinical trial of fucoxanthin supplementation in Japanese obese subjects [130]. They explored the effect of fucoxanthin (1 or $3 \mathrm{mg}$ daily) in a double-blind placebo-controlled study. Capsules containing fucoxanthin or placebo capsules were administered for 4 weeks to male and female Japanese adults with a BMI of more than $25 \mathrm{~kg} / \mathrm{m}^{2}$. In accordance with Reference [126], they observed a significant reduction of the relative (ratio versus before treatment) body weight, BMI, and visceral fat area in the $3 \mathrm{mg} /$ day fucoxanthin group compared to the placebo group.

Other clinical trials have been conducted or are still recruiting volunteers to test many hypotheses of clinical effects implicating fucoxanthin, alone or combined with other compounds (Table 5). These studies are listed in the "ClinicalTrials.gov" database [131], a resource provided by the U.S. National Library of Medicine, containing privately and publicly funded clinical studies conducted around the world. 
Table 5. Clinical trials involving Fucoxanthin.

\begin{tabular}{|c|c|c|c|c|c|c|c|}
\hline NCT Number & Title & Conditions & Interventions & Phases & Study Designs & Start Date & Locations \\
\hline NCT02875392 & $\begin{array}{l}\text { Fucoidan Improves the } \\
\text { Metabolic Profiles of } \\
\text { Patients With } \\
\text { Non-alcoholic Fatty Liver } \\
\text { Disease (NAFLD) }\end{array}$ & $\begin{array}{l}\text { Non-alcoholic } \\
\text { Fatty Liver } \\
\text { Disease }\end{array}$ & $\begin{array}{l}\text { Other: } 275 \text { mg Oligo Fucoidan } \\
+275 \text { mg HS Fucoxanthin|Other: } \\
\text { placebo pills }\end{array}$ & $\begin{array}{l}\text { NA } \\
\text { (unknown } \\
\text { status) }\end{array}$ & $\begin{array}{c}\text { Allocation: Randomized } \\
\text { Intervention Model: Parallel } \\
\text { Assignment } \\
\text { Masking: Double (Participant, Care } \\
\text { Provider) } \\
\text { Primary Purpose: Treatment }\end{array}$ & November 2016 & $\begin{array}{l}\text { WanFangH, Taipei, } \\
\text { Taiwan }\end{array}$ \\
\hline NCT03625284 & $\begin{array}{c}\text { Oral Dietary } \\
\text { Fucoxanthin-Rich } \\
\text { Supplement for Liver } \\
\text { Health }\end{array}$ & $\begin{array}{l}\text { Non-Alcoholic } \\
\text { Fatty Liver }\end{array}$ & $\begin{array}{l}\text { Dietary Supplement: Placebo } \\
\text { Dietary Supplement: FucoVital }\end{array}$ & $\begin{array}{l}\text { NA } \\
\text { (unknown } \\
\text { status) }\end{array}$ & $\begin{array}{c}\text { Allocation: Randomized } \\
\text { Intervention Model: Parallel } \\
\text { Assignment } \\
\text { Masking: Quadruple (Participant, } \\
\text { Care Provider, Investigator, } \\
\text { Outcomes Assessor) } \\
\text { Primary Purpose: Prevention }\end{array}$ & 10 September 2018 & $\begin{array}{l}\text { Assaf-Harofeh Medical } \\
\text { Center, Israël }\end{array}$ \\
\hline NCT03613740 & $\begin{array}{l}\text { Effect of Fucoxanthin on } \\
\text { the Components of the } \\
\text { Metabolic Syndrome, } \\
\text { Insulin Sensitivity and } \\
\text { Insulin Secretion }\end{array}$ & $\begin{array}{l}\text { Metabolic } \\
\text { Syndrome }\end{array}$ & $\begin{array}{l}\text { Drug: Fucoxanthin|Drug: } \\
\text { Placebo }\end{array}$ & $\begin{array}{l}\text { Phase 2 } \\
\text { (still } \\
\text { recruiting) }\end{array}$ & $\begin{array}{c}\text { Allocation: Randomized } \\
\text { Intervention Model: Parallel } \\
\text { Assignment } \\
\text { Masking: Double (Participant, } \\
\text { Investigator) } \\
\text { Primary Purpose: Treatment }\end{array}$ & 30 September 2019 & $\begin{array}{l}\text { Instituto de Terapéutica } \\
\text { Experimental y Clínica. } \\
\text { Centro Universitario de } \\
\text { Ciencias de la Salud. } \\
\text { Guadalajara, Mexico }\end{array}$ \\
\hline NCT04288544 & $\begin{array}{l}\text { Health Promoting Effects } \\
\text { of the Microalgae } \\
\text { Phaeodactylum } \\
\text { Tricornutum }\end{array}$ & $\begin{array}{l}\text { Human } \\
\text { Nutrition, } \\
\text { Omega-3 Fatty } \\
\text { Acids, } \\
\text { Microalgae } \\
\text { Micronutrients }\end{array}$ & $\begin{array}{c}\text { Dietary Supplement: Microalgae } \\
\text { Dietary Supplement: } \\
\text { Omega-3-fatty acid capsule } \\
\text { Dietary Supplement: sea fish }\end{array}$ & $\begin{array}{l}\text { NA } \\
\text { (Enrolling by } \\
\text { invitation) }\end{array}$ & $\begin{array}{c}\text { Allocation: Non-Randomized } \\
\text { Intervention Model: Crossover } \\
\text { Assignment } \\
\text { Masking: None (Open Label) } \\
\text { Primary Purpose: Supportive Care }\end{array}$ & 25 February 2020 & $\begin{array}{c}\text { lena Stiefvatter, Stuttgart, } \\
\text { Germany } \\
\text { University of } \\
\text { Hohenheim, Stuttgart, } \\
\text { Germany }\end{array}$ \\
\hline
\end{tabular}

NA: Not Applicable; NCT: Number Clinical Trials (identifier); Source “ClinicalTrials.gov" database [131]. 


\section{Discussion}

The hallmarks of cancer, first described in 2000, comprise six biological capabilities acquired during the multistep development of human tumors: self-sufficiency in growth signals, insensitivity to growth inhibiting signals, the ability to avoid apoptosis and to replicate indefinitely, the induction of angiogenesis, and the ability to form metastases [132]. Later, two distinctive emerging capacities were added, i.e., the deregulation of cellular energy metabolism and the ability to avoid destruction by the immune system, without neglecting two characteristics favoring cancers, i.e., inflammation favoring tumors as well as instability and mutations of the genome [104].

On a structural level, metabolites of fucoxanthin are fucoxanthinol, which has been found to be more efficient than fucoxanthin, and amarouciaxanthin A [46]. Curiously, to our knowledge, the effects of amarouciaxanthin A on cancer prevention and therapy have not been clarified yet. However, considering those hallmarks, fucoxanthin and its derivatives appears to be a promising bioactive compound for treatment of cancer development and aggressiveness. Nonetheless, a few points need to be deepened, such as genomic instability through deregulation of DNA repair pathways, which can initiate cancer and finally result in resistance to chemo- and radio-therapy. It may be useful to study whether fucoxanthin has an inhibitory effect on DNA repair pathways, such as nucleotide excision repair, mismatch repair, and double-strand break repairs, which are involved in cancer therapy resistance $[133,134]$.

Moreover, concerning angiogenesis, despite promising results showing that fucoxanthin downregulates the phosphorylation of FGF-2 and also involves decreased levels of VEGF-C, VEGF receptor-3, NF-KB, phospho-Akt, and phospho-PI3K in HLEC [88], further studies could elucidate the exact molecular mechanisms underlying the anti-angiogenic effect of fucoxanthin, especially those related to VEGF and FGF-2. This should lead to enhance the exploration of therapeutic potential of marine-derived molecules such as fucoxanthin. Indeed, angiogenesis is recognized as one of the hallmarks of cancer, a crucial step in the transition of tumors from a dormant stage to a malignant stage, and playing an essential role in tumor growth, invasion, and metastasis [104]. Key proteins implicated in the regulation of cellular adhesion, migration, and EMT are, for the most part, inhibited by fucoxanthin or its metabolite fucoxanthinol [20,99].

The role of fucoxanthin in the ability of tumor cells to deregulate cellular energy production, known as the "Warburg effect", remains to be explored. It is described as the increased utilization of glycolysis rather than oxidative phosphorylation by cancer cells because of their energy requirement under normal oxygen conditions [135]. Zeaxanthin, another carotenoid, which is structurally similar to fucoxanthin, was shown to block hypoxia-induced VEGF secretion in cultured human retinal pigment epithelial cells and seems to modulate hypoxia-inducible factors-1 (HIF-1), which has been recognized as an important cancer drug target [136]. Extensive studies are necessary to complete potential inhibitory effects of fucoxanthin on the Warburg effect but also on two other hallmarks: enabling replicative immortality and the capacity of cancer cells to avoid immune destruction.

Fucoxanthin and more importantly its metabolite fucoxanthinol are able to reduce NF- $\mathrm{kB}$ activation $[19,53,78,80,98]$, which favor apoptosis. NF- $\mathrm{kB}$ is also implicated in inflammation, which promotes cell proliferation and is linked to carcinogenesis. Indeed, inflammatory responses play decisive roles at different stages of tumor development [104]. Interestingly, Lin et al. found that $D$. salina carotenoids extract induced a downregulation of the expression of pro-inflammatory genes and a decrease of NF-KB activation in an antiviral context [123]. In addition, a few studies highlighted the anti-inflammatory potential of fucoxanthin in lipopolysaccharide (LPS)-induced inflammation [25,137]. In vivo, fucoxanthin was also found to decrease the expression of inflammatory cytokines in a prophylactic manner in the LPS-induced sepsis mouse model [42]. Furthermore, in combination with rosmarinic acid, fucoxanthin seems to exert anti-inflammatory effects by downregulating NRLP3-inflammasome and increasing the NFE2L2/Nrf2 signaling pathway [15]. However, further investigations are necessary to evaluate more precisely the anti-inflammatory effects of fucoxanthin in bacterial and especially viral infection, as well as its involvement in tumor progression. 
The knowledge of the correlation between inflammation and tumor development should give the opportunity of developing new candidates for therapeutics. This could be used in combination with conventional therapeutic approaches, such as chemotherapy, radiotherapy, and targeted therapy [138]. Current findings suggest that fucoxanthin and its derived compounds could be effective for anticancer treatment and these carotenoids could be useful to support therapeutic strategies in combination with common cancer drugs. As described above (Section 5), fucoxanthin leads to improvement of the chemotherapeutic efficacy of cisplatin by targeting the DNA repair pathway [68]. Furthermore, fucoxanthin has been shown to act in synergy with other conventional drugs, such as troglitazone, a specific ligand for peroxisome proliferator-activated receptor (PPAR) gamma. Both drugs had a cytotoxic effect on Caco-2 cells while its separated administration had no effects [72]. In the same way, Ye et al. demonstrated that the use of a combined treatment with fucoxanthin and TRAIL could be a useful strategy against TRAIL-resistant cervical cancer by acting on the upregulation of the PI3K/Akt pathway [83,139]. Furthermore, Eid et al. also showed that fucoxanthin enhanced, synergistically, cytotoxicity induced by doxorubicin in human colorectal adenocarcinoma cells, by inhibiting the function of the ATP-Binding Cassette transporters [140]. These studies led to suggest that these biomolecules could be effective for cancer therapy as chemosensitizers, adjuvants, or even as active substances.

\section{Conclusions}

Cellular and animal studies have shown that fucoxanthin has anticancer effects. However, investigation of this role in humans is lacking. Clinical trials are required to assess the effect of fucoxanthin in close connection with the study of the mechanisms involved in the antitumoral action of fucoxanthin. Moreover, anticancer effects of fucoxanthin are regulated by several mechanisms leading to cell cycle arrest, induction of cell death and DNA damages, inhibition of metastasis-related migration, invasion and epithelial-mesenchymal transition, anti-angiogenic, and anti-inflammatory effects. Furthermore, combined treatments of fucoxanthin or fucoxanthinol with usual anticancer treatments can support conventional therapeutic strategies by reducing drug resistance. Indeed, as an anticancer molecule, fucoxanthinol appears to be a more effective bioactive compound than fucoxanthin. Therefore, the potential use of fucoxanthinol and other fucoxanthin derivatives (such as apo-9'-fucoxanthinone and apo-13-fucoxanthinone) as co-adjuvant agents in the treatment of cancer should be further investigated. However, further studies are necessary for precise and complete inhibitory effects of fucoxanthin and its derivatives, but regarding these hallmarks, fucoxanthin appears to be a promising compound for cancer therapy.

Author Contributions: All authors contributed equally to writing-review and editing, and have read and agreed to the published version of the manuscript.

Funding: This research was funded by Ligue contre le Cancer, comité de la Sarthe, grant IRAPIM.

Conflicts of Interest: The authors declare no conflict of interest. The funders had no role in the design of the study; in the collection, analyses, or interpretation of data; in the writing of the manuscript, or in the decision to publish the results.

$\begin{array}{ll}\text { Abbreviations } \\ \text { AP-1 } & \text { activator protein-1 } \\ \text { ASC } & \text { apoptosis-associated speck-like protein } \\ \text { ATM } & \text { ataxia telangiectasia mutated protein } \\ \text { ATR } & \text { ataxia telangiectasia and Rad3-related protein } \\ \text { BMI } & \text { body mass index } \\ \text { CAT } & \text { catalase }\end{array}$




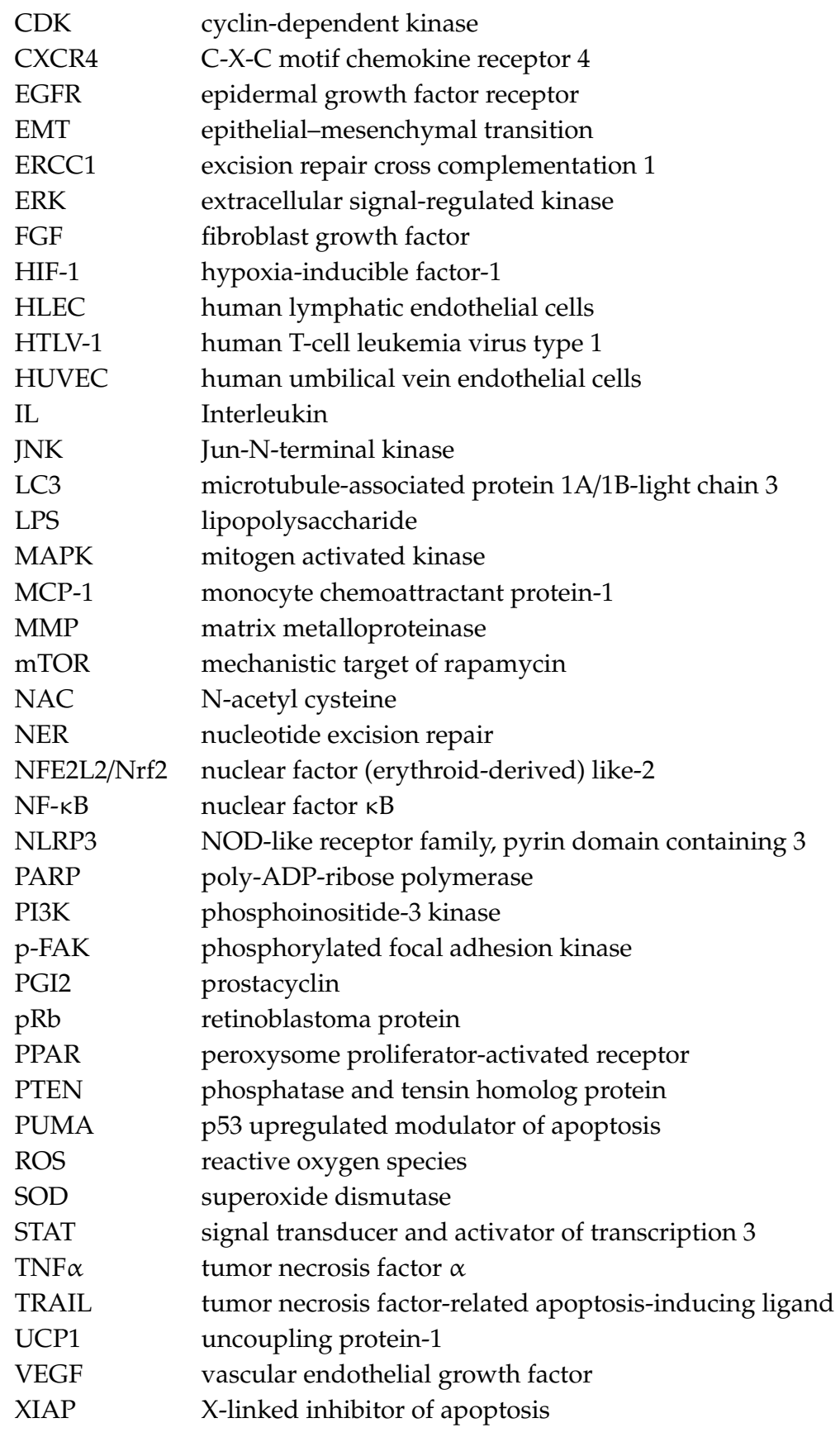

\section{References}

1. Yabuzaki, J. Carotenoids Database: Structures, chemical fingerprints and distribution among organisms. Database 2017, 2017. [CrossRef]

2. Armstrong, G.A.; Hearst, J.E. Genetics and molecular biology of carotenoid pigment biosynthesis. FASEB J. 1996, 10, 228-237. [CrossRef]

3. Tinkler, J.H.; Böhm, F.; Schalch, W.; Truscott, T.G. Dietary carotenoids protect human cells from damage. J. Photochem. Photobiol. B 1994, 26, 283-285. [CrossRef]

4. Foote, C.S.; Denny, R.W. Chemistry of singlet oxygen. VII. Quenching by .beta.-carotene. J. Am. Chem. Soc. 1968, 90, 6233-6235. [CrossRef]

5. Jørgensen, K.; Skibsted, L.H. Carotenoid scavenging of radicals. Effect of carotenoid structure and oxygen partial pressure on antioxidative activity. Z. Lebensm. Unters. Forsch. 1993, 196, 423-429. [CrossRef] [PubMed]

6. Willstätter, R.; Page, H.J. Untersuchungen über Chlorophyll. XXIV. Über die Pigmente der Braunalgen. Justus Liebigs Ann. Chem. 1914, 404, 237-271. [CrossRef] 
7. Bonnett, R.; Mallams, A.K.; Tee, J.L.; Weedon, B.C.L.; McCormick, A. Fucoxanthin and related pigments. Chem. Commun. Lond. 1966, 515. [CrossRef]

8. Bonnett, R.; Mallams, A.K.; Spark, A.A.; Tee, J.L.; Weedon, B.C.L.; McCormick, A. Carotenoids and related compounds. Part XX. Structure and reactions of fucoxanthin. J. Chem. Soc. C Org. 1969, 429. [CrossRef]

9. Takaichi, S. Carotenoids in Algae: Distributions, Biosyntheses and Functions. Mar. Drugs 2011, 9, 1101-1118. [CrossRef] [PubMed]

10. Liaaen-Jensen, S. Marine Carotenoids. In Marine Natural Products; Elsevier: Amsterdam, The Netherlands, 1978; pp. 1-73. ISBN 978-0-12-624002-3.

11. Kim, S.M.; Jung, Y.-J.; Kwon, O.-N.; Cha, K.H.; Um, B.-H.; Chung, D.; Pan, C.-H. A potential commercial source of fucoxanthin extracted from the microalga Phaeodactylum tricornutum. Appl. Biochem. Biotechnol. 2012, 166, 1843-1855. [CrossRef] [PubMed]

12. Maeda, H.; Hosokawa, M.; Sashima, T.; Funayama, K.; Miyashita, K. Fucoxanthin from edible seaweed, Undaria pinnatifida, shows antiobesity effect through UCP1 expression in white adipose tissues. Biochem. Biophys. Res. Commun. 2005, 332, 392-397. [CrossRef] [PubMed]

13. Maeda, H.; Hosokawa, M.; Sashima, T.; Miyashita, K. Dietary Combination of Fucoxanthin and Fish Oil Attenuates the Weight Gain of White Adipose Tissue and Decreases Blood Glucose in Obese/Diabetic KK- $A$ ${ }^{y}$ Mice. J. Agric. Food Chem. 2007, 55, 7701-7706. [CrossRef] [PubMed]

14. Ganesan, P.; Matsubara, K.; Sugawara, T.; Hirata, T. Marine algal carotenoids inhibit angiogenesis by down-regulating FGF-2-mediated intracellular signals in vascular endothelial cells. Mol. Cell. Biochem. 2013, 380, 1-9. [CrossRef] [PubMed]

15. Rodríguez-Luna, A.; Ávila-Román, J.; Oliveira, H.; Motilva, V.; Talero, E. Fucoxanthin and Rosmarinic Acid Combination Has Anti-Inflammatory Effects through Regulation of NLRP3 Inflammasome in UVB-Exposed HaCaT Keratinocytes. Mar. Drugs 2019, 17, 451. [CrossRef] [PubMed]

16. Hwang, P.-A.; Phan, N.N.; Lu, W.-J.; Ngoc Hieu, B.T.; Lin, Y.-C. Low-molecular-weight fucoidan and high-stability fucoxanthin from brown seaweed exert prebiotics and anti-inflammatory activities in Caco-2 cells. Food Nutr. Res. 2016, 60, 32033. [CrossRef] [PubMed]

17. Mayer, C.; Côme, M.; Ulmann, L.; Chini Zittelli, G.; Faraloni, C.; Nazih, H.; Ouguerram, K.; Chénais, B.; Mimouni, V. Preventive Effects of the Marine Microalga Phaeodactylum tricornutum, Used as a Food Supplement, on Risk Factors Associated with Metabolic Syndrome in Wistar Rats. Nutrients 2019, 11, 1069. [CrossRef]

18. Airanthi, M.K.W.-A.; Hosokawa, M.; Miyashita, K. Comparative Antioxidant Activity of Edible Japanese Brown Seaweeds. J. Food Sci. 2011, 76, C104-C111. [CrossRef]

19. Tafuku, S.; Ishikawa, C.; Yasumoto, T.; Mori, N. Anti-neoplastic effects of fucoxanthin and its deacetylated product, fucoxanthinol, on Burkitt's and Hodgkin's lymphoma cells. Oncol. Rep. 2012, 28, 1512-1518. [CrossRef]

20. Rokkaku, T.; Kimura, R.; Ishikawa, C.; Yasumoto, T.; Senba, M.; Kanaya, F.; Mori, N. Anticancer effects of marine carotenoids, fucoxanthin and its deacetylated product, fucoxanthinol, on osteosarcoma. Int. J. Oncol. 2013, 43, 1176-1186. [CrossRef]

21. Heo, S.-J.; Yoon, W.-J.; Kim, K.-N.; Ahn, G.-N.; Kang, S.-M.; Kang, D.-H.; Affan, A.; Oh, C.; Jung, W.-K.; Jeon, Y.-J. Evaluation of anti-inflammatory effect of fucoxanthin isolated from brown algae in lipopolysaccharidestimulated RAW 264.7 macrophages. Food Chem. Toxicol. 2010, 48, 2045-2051. [CrossRef]

22. Kim, S.M.; Kang, S.-W.; Kwon, O.-N.; Chung, D.; Pan, C.-H. Fucoxanthin as a major carotenoid in Isochrysis aff. galbana: Characterization of extraction for commercial application. J. Korean Soc. Appl. Biol. Chem. 2012, 55, 477-483. [CrossRef]

23. Imbs, T.I.; Ermakova, S.P.; Fedoreyev, S.A.; Anastyuk, S.D.; Zvyagintseva, T.N. Isolation of Fucoxanthin and Highly Unsaturated Monogalactosyldiacylglycerol from Brown Alga Fucus evanescens C Agardh and In Vitro Investigation of Their Antitumor Activity. Mar. Biotechnol. 2013, 15, 606-612. [CrossRef] [PubMed]

24. Zaragozá, M.C.; López, D.; Sáiz, P.M.; Poquet, M.; Pérez, J.; Puig-Parellada, P.; Màrmol, F.; Simonetti, P.; Gardana, C.; Lerat, Y.; et al. Toxicity and Antioxidant Activity in Vitro and in Vivo of Two Fucus vesiculosus Extracts. J. Agric. Food Chem. 2008, 56, 7773-7780. [CrossRef] [PubMed]

25. Kim, K.-N.; Heo, S.-J.; Kang, S.-M.; Ahn, G.; Jeon, Y.-J. Fucoxanthin induces apoptosis in human leukemia HL-60 cells through a ROS-mediated Bcl-xL pathway. Toxicol. In Vitro 2010, 24, 1648-1654. [CrossRef] 
26. Kanazawa, K.; Ozaki, Y.; Hashimoto, T.; Das, S.K.; Matsushita, S.; Hirano, M.; Okada, T.; Komoto, A.; Mori, N.; Nakatsuka, M. Commercial-scale Preparation of Biofunctional Fucoxanthin from Waste Parts of Brown Sea Algae Laminalia japonica. Food Sci. Technol. Res. 2008, 14, 573-582. [CrossRef]

27. Xiao, X.; Si, X.; Yuan, Z.; Xu, X.; Li, G. Isolation of fucoxanthin from edible brown algae by microwave-assisted extraction coupled with high-speed countercurrent chromatography: Other Techniques. J. Sep. Sci. 2012, 35, 2313-2317. [CrossRef]

28. Sangeetha, R.K.; Bhaskar, N.; Divakar, S.; Baskaran, V. Bioavailability and metabolism of fucoxanthin in rats: Structural characterization of metabolites by LC-MS (APCI). Mol. Cell. Biochem. 2010, 333, 299-310. [CrossRef]

29. Mori, K.; Ooi, T.; Hiraoka, M.; Oka, N.; Hamada, H.; Tamura, M.; Kusumi, T. Fucoxanthin and Its Metabolites in Edible Brown Algae Cultivated in Deep Seawater. Mar. Drugs 2004, 2, 63-72. [CrossRef]

30. Chung, T.-W.; Choi, H.-J.; Lee, J.-Y.; Jeong, H.-S.; Kim, C.-H.; Joo, M.; Choi, J.-Y.; Han, C.-W.; Kim, S.-Y.; Choi, J.-S.; et al. Marine algal fucoxanthin inhibits the metastatic potential of cancer cells. Biochem. Biophys. Res. Commun. 2013, 439, 580-585. [CrossRef]

31. Jaswir, I.; Noviendri, D.; Salleh, H.M.; Miyashita, K. Fucoxanthin Extractions of Brown Seaweeds and Analysis of Their Lipid Fraction in Methanol. Food Sci. Technol. Res. 2012, 18, 251-257. [CrossRef]

32. Nagappan, H.; Pee, P.P.; Kee, S.H.Y.; Ow, J.T.; Yan, S.W.; Chew, L.Y.; Kong, K.W. Malaysian brown seaweeds Sargassum siliquosum and Sargassum polycystum: Low density lipoprotein (LDL) oxidation, angiotensin converting enzyme (ACE), $\alpha$-amylase, and $\alpha$-glucosidase inhibition activities. Food Res. Int. Ott. Ont. 2017, 99, 950-958. [CrossRef] [PubMed]

33. Heo, S.-J.; Jeon, Y.-J. Protective effect of fucoxanthin isolated from Sargassum siliquastrum on UV-B induced cell damage. J. Photochem. Photobiol. B 2009, 95, 101-107. [CrossRef] [PubMed]

34. Heo, S.-J.; Yoon, W.-J.; Kim, K.-N.; Oh, C.; Choi, Y.-U.; Yoon, K.-T.; Kang, D.-H.; Qian, Z.-J.; Choi, I.-W.; Jung, W.-K. Anti-inflammatory effect of fucoxanthin derivatives isolated from Sargassum siliquastrum in lipopolysaccharide-stimulated RAW 264.7 macrophage. Food Chem. Toxicol. Int. J. Publ. Br. Ind. Biol. Res. Assoc. 2012, 50, 3336-3342. [CrossRef] [PubMed]

35. Maeda, H.; Fukuda, S.; Izumi, H.; Saga, N. Anti-Oxidant and Fucoxanthin Contents of Brown Alga Ishimozuku (Sphaerotrichia divaricata) from the West Coast of Aomori, Japan. Mar. Drugs 2018, 16, 255. [CrossRef] [PubMed]

36. Nurrochmad, A.; Wirasti, W.; Dirman, A.; Lukitaningsih, E.; Rahmawati, A.; Fakhrudin, N. Effects of Antioxidant, Anti-Collagenase, Anti-Elastase, Anti-Tyrosinase of The Extract and Fraction From Turbinaria decurrens Bory. Indones. J. Pharm. 2018, 29, 188. [CrossRef]

37. Petrushkina, M.; Gusev, E.; Sorokin, B.; Zotko, N.; Mamaeva, A.; Filimonova, A.; Kulikovskiy, M.; Maltsev, Y.; Yampolsky, I.; Guglya, E.; et al. Fucoxanthin production by heterokont microalgae. Algal Res. 2017, 24, 387-393. [CrossRef]

38. Allen, M.B.; Goodwin, T.W.; Phagpolngarm, S. Carotenoid Distribution in Certain Naturally Occurring Algae and in some Artificially Induced Mutants of Chlorella pyrenoidosa. J. Gen. Microbiol. 1960, 23, 93-103. [CrossRef]

39. Withers, N.W.; Fiksdahl, A.; Tuttle, R.C.; Liaaen-Jensen, S. Carotenoids of the chrysophyceae. Comp. Biochem. Physiol. Part. B Comp. Biochem. 1981, 68, 345-349. [CrossRef]

40. Foo, S.C.; Md. Yusoff, F.; Ismail, M.; Basri, M.; Chan, K.W.; Khong, N.M.H.; Yau, S.K. Production of fucoxanthin-rich fraction (FxRF) from a diatom, Chaetoceros calcitrans (Paulsen) Takano 1968. Algal Res. 2015, 12, 26-32. [CrossRef]

41. Xia, S.; Wang, K.; Wan, L.; Li, A.; Hu, Q.; Zhang, C. Production, Characterization, and Antioxidant Activity of Fucoxanthin from the Marine Diatom Odontella aurita. Mar. Drugs 2013, 11, 2667-2681. [CrossRef]

42. Su, J.; Guo, K.; Huang, M.; Liu, Y.; Zhang, J.; Sun, L.; Li, D.; Pang, K.-L.; Wang, G.; Chen, L.; et al. Fucoxanthin, a Marine Xanthophyll Isolated From Conticribra weissflogii ND-8: Preventive Anti-Inflammatory Effect in a Mouse Model of Sepsis. Front. Pharmacol. 2019, 10, 906. [CrossRef]

43. Crupi, P.; Toci, A.T.; Mangini, S.; Wrubl, F.; Rodolfi, L.; Tredici, M.R.; Coletta, A.; Antonacci, D. Determination of fucoxanthin isomers in microalgae (Isochrysis sp.) by high-performance liquid chromatography coupled with diode-array detector multistage mass spectrometry coupled with positive electrospray ionization: Fucoxanthin isomers in Isochrysis sp. Rapid Commun. Mass Spectrom. 2013, 27, 1027-1035. [CrossRef] [PubMed] 
44. Pasquet, V.; Chérouvrier, J.-R.; Farhat, F.; Thiéry, V.; Piot, J.-M.; Bérard, J.-B.; Kaas, R.; Serive, B.; Patrice, T.; Cadoret, J.-P.; et al. Study on the microalgal pigments extraction process: Performance of microwave assisted extraction. Process. Biochem. 2011, 46,59-67. [CrossRef]

45. Sugawara, T.; Baskaran, V.; Tsuzuki, W.; Nagao, A. Brown Algae Fucoxanthin Is Hydrolyzed to Fucoxanthinol during Absorption by Caco-2 Human Intestinal Cells and Mice. J. Nutr. 2002, 132, 946-951. [CrossRef] [PubMed]

46. Asai, A.; Sugawara, T.; Ono, H.; Nagao, A. Biotransformation of Fucoxanthinol into Amarouciaxanthin a in mice and HepG2 cells: Formation and cytotoxicity of Fucoxanthin metabolites. Drug Metab. Dispos. 2004, 32, 205-211. [CrossRef] [PubMed]

47. Komba, S.; Kotake-Nara, E.; Tsuzuki, W. Degradation of Fucoxanthin to Elucidate the Relationship between the Fucoxanthin Molecular Structure and Its Antiproliferative Effect on Caco-2 Cells. Mar. Drugs 2018, 16, 275. [CrossRef] [PubMed]

48. Doi, Y.; Ishibashi, M.; Yamaguchi, N.; Kobayashi, J. Isolation of Apo-9'-fucoxanthinone from the Cultured Marine Dinoflagellate Amphidinium sp. J. Nat. Prod. 1995, 58, 1097-1099. [CrossRef]

49. Shaw, B.A.; Andersen, R.J.; Harrison, P.J. Feeding deterrence properties of apo-fucoxanthinoids from marine diatoms. I. Chemical structures of apo-fucoxanthinoids produced by Phaeodactylum tricornutum. Mar. Biol. 1995, 124, 467-472. [CrossRef]

50. Beppu, F.; Niwano, Y.; Tsukui, T.; Hosokawa, M.; Miyashita, K. Single and repeated oral dose toxicity study of fucoxanthin (FX), a marine carotenoid, in mice. J. Toxicol. Sci. 2009, 34, 501-510. [CrossRef]

51. Almeida, T.P.; Ferreira, J.; Vettorazzi, A.; Azqueta, A.; Rocha, E.; Ramos, A.A. Cytotoxic activity of fucoxanthin, alone and in combination with the cancer drugs imatinib and doxorubicin, in CML cell lines. Environ. Toxicol. Pharmacol. 2018, 59, 24-33. [CrossRef]

52. Ishikawa, C.; Tafuku, S.; Kadekaru, T.; Sawada, S.; Tomita, M.; Okudaira, T.; Nakazato, T.; Toda, T.; Uchihara, J.-N.; Taira, N.; et al. Anti-adult T-cell leukemia effects of brown algae fucoxanthin and its deacetylated product, fucoxanthinol. Int. J. Cancer 2008, 123, 2702-2712. [CrossRef] [PubMed]

53. Yamamoto, K.; Ishikawa, C.; Katano, H.; Yasumoto, T.; Mori, N. Fucoxanthin and its deacetylated product, fucoxanthinol, induce apoptosis of primary effusion lymphomas. Cancer Lett. 2011, 300, 225-234. [CrossRef] [PubMed]

54. Wang, L.; Zeng, Y.; Liu, Y.; Hu, X.; Li, S.; Wang, Y.; Li, L.; Lei, Z.; Zhang, Z. Fucoxanthin induces growth arrest and apoptosis in human bladder cancer T24 cells by up-regulation of p21 and down-regulation of mortalin. Acta Biochim. Biophys. Sin. 2014, 46, 877-884. [CrossRef] [PubMed]

55. Kim, K.-N.; Ahn, G.; Heo, S.-J.; Kang, S.-M.; Kang, M.-C.; Yang, H.-M.; Kim, D.; Roh, S.W.; Kim, S.-K.; Jeon, B.-T.; et al. Inhibition of tumor growth in vitro and in vivo by fucoxanthin against melanoma B16F10 cells. Environ. Toxicol. Pharmacol. 2013, 35, 39-46. [CrossRef] [PubMed]

56. Yu, R.-X.; Hu, X.-M.; Xu, S.-Q.; Jiang, Z.-J.; Yang, W. Effects of fucoxanthin on proliferation and apoptosis in human gastric adenocarcinoma MGC-803 cells via JAK/STAT signal pathway. Eur. J. Pharmacol. 2011, 657, 10-19. [CrossRef]

57. Das, S.K.; Hashimoto, T.; Shimizu, K.; Yoshida, T.; Sakai, T.; Sowa, Y.; Komoto, A.; Kanazawa, K. Fucoxanthin induces cell cycle arrest at G0/G1 phase in human colon carcinoma cells through up-regulation of p21WAF1/Cip1. Biochim. Biophys. Acta BBA Gen. Subj. 2005, 1726, 328-335. [CrossRef]

58. Satomi, Y. Fucoxanthin induces GADD45A expression and G1 arrest with SAPK/JNK activation in LNCap human prostate cancer cells. Anticancer Res. 2012, 32, 807-813.

59. Satomi, Y.; Nishino, H. Implication of mitogen-activated protein kinase in the induction of G1 cell cycle arrest and gadd 45 expression by the carotenoid fucoxanthin in human cancer cells. Biochim. Biophys. Acta 2009, 1790, 260-266. [CrossRef]

60. Yoshiko, S.; Hoyoku, N. Fucoxanthin, a natural carotenoid, induces G1 arrest and GADD45 gene expression in human cancer cells. In Vivo Athens Greece 2007, 21, 305-309.

61. Okuzumi, J.; Nishino, H.; Murakoshi, M.; Iwashima, A.; Tanaka, Y.; Yamane, T.; Fujita, Y.; Takahashi, T. Inhibitory effects of fucoxanthin, a natural carotenoid, on $\mathrm{N}$-myc expression and cell cycle progression in human malignant tumor cells. Cancer Lett. 1990, 55, 75-81. [CrossRef]

62. Das, S.K.; Hashimoto, T.; Kanazawa, K. Growth inhibition of human hepatic carcinoma HepG2 cells by fucoxanthin is associated with down-regulation of cyclin D. Biochim. Biophys. Acta 2008, 1780, 743-749. [CrossRef] 
63. Neumann, U.; Derwenskus, F.; Flaiz Flister, V.; Schmid-Staiger, U.; Hirth, T.; Bischoff, S. Fucoxanthin, A Carotenoid Derived from Phaeodactylum tricornutum Exerts Antiproliferative and Antioxidant Activities in Vitro. Antioxidants 2019, 8, 183. [CrossRef]

64. Liu, C.-L.; Huang, Y.-S.; Hosokawa, M.; Miyashita, K.; Hu, M.-L. Inhibition of proliferation of a hepatoma cell line by fucoxanthin in relation to cell cycle arrest and enhanced gap junctional intercellular communication. Chem. Biol. Interact. 2009, 182, 165-172. [CrossRef]

65. Hou, L.; Gao, C.; Chen, L.; Hu, G.; Xie, S. Essential role of autophagy in fucoxanthin-induced cytotoxicity to human epithelial cervical cancer HeLa cells. Acta Pharmacol. Sin. 2013, 34, 1403-1410. [CrossRef]

66. Moreau, D.; Tomasoni, C.; Jacquot, C.; Kaas, R.; Le Guedes, R.; Cadoret, J.-P.; Muller-Feuga, A.; Kontiza, I.; Vagias, C.; Roussis, V.; et al. Cultivated microalgae and the carotenoid fucoxanthin from Odontella aurita as potent anti-proliferative agents in bronchopulmonary and epithelial cell lines. Environ. Toxicol. Pharmacol. 2006, 22, 97-103. [CrossRef] [PubMed]

67. Mei, C.; Zhou, S.; Zhu, L.; Ming, J.; Zeng, F.; Xu, R. Antitumor Effects of Laminaria Extract Fucoxanthin on Lung Cancer. Mar. Drugs 2017, 15, 39. [CrossRef]

68. Liu, C.-L.; Lim, Y.-P.; Hu, M.-L. Fucoxanthin enhances cisplatin-induced cytotoxicity via NFkB-mediated pathway and downregulates DNA repair gene expression in human hepatoma HepG2 cells. Mar. Drugs 2013, 11, 50-66. [CrossRef] [PubMed]

69. Foo, S.C.; Md. Yusoff, F.; Imam, M.U.; Foo, J.B.; Ismail, N.; Azmi, N.H.; Tor, Y.S.; Khong, N.M.H.; Ismail, M. Increased fucoxanthin in Chaetoceros calcitrans extract exacerbates apoptosis in liver cancer cells via multiple targeted cellular pathways. Biotechnol. Rep. 2019, 21, e00296. [CrossRef] [PubMed]

70. Zhu, Y.; Cheng, J.; Min, Z.; Yin, T.; Zhang, R.; Zhang, W.; Hu, L.; Cui, Z.; Gao, C.; Xu, S.; et al. Effects of fucoxanthin on autophagy and apoptosis in SGC-7901cells and the mechanism. J. Cell. Biochem. 2018, 119, 7274-7284. [CrossRef] [PubMed]

71. Garg, S.; Afzal, S.; Elwakeel, A.; Sharma, D.; Radhakrishnan, N.; Dhanjal, J.K.; Sundar, D.; Kaul, S.C.; Wadhwa, R. Marine Carotenoid Fucoxanthin Possesses Anti-Metastasis Activity: Molecular Evidence. Mar. Drugs 2019, 17, 338. [CrossRef]

72. Hosokawa, M.; Kudo, M.; Maeda, H.; Kohno, H.; Tanaka, T.; Miyashita, K. Fucoxanthin induces apoptosis and enhances the antiproliferative effect of the PPAR $\gamma$ ligand, troglitazone, on colon cancer cells. Biochim. Biophys. Acta BBA Gen. Subj. 2004, 1675, 113-119. [CrossRef] [PubMed]

73. Lopes-Costa, E.; Abreu, M.; Gargiulo, D.; Rocha, E.; Ramos, A.A. Anticancer effects of seaweed compounds fucoxanthin and phloroglucinol, alone and in combination with 5-fluorouracil in colon cells. J. Toxicol. Environ. Health A 2017, 80, 776-787. [CrossRef] [PubMed]

74. Konishi, I.; Hosokawa, M.; Sashima, T.; Kobayashi, H.; Miyashita, K. Halocynthiaxanthin and fucoxanthinol isolated from Halocynthia roretzi induce apoptosis in human leukemia, breast and colon cancer cells. Comp. Biochem. Physiol. Part. C Toxicol. Pharmacol. 2006, 142, 53-59. [CrossRef] [PubMed]

75. Zhang, Z.; Zhang, P.; Hamada, M.; Takahashi, S.; Xing, G.; Liu, J.; Sugiura, N. Potential chemoprevention effect of dietary fucoxanthin on urinary bladder cancer EJ-1 cell line. Oncol. Rep. 2008, 20, 1099-1103. [CrossRef]

76. Kotake-Nara, E.; Kushiro, M.; Zhang, H.; Sugawara, T.; Miyashita, K.; Nagao, A. Carotenoids Affect Proliferation of Human Prostate Cancer Cells. J. Nutr. 2001, 131, 3303-3306. [CrossRef]

77. Kotake-Nara, E.; Sugawara, T.; Nagao, A. Antiproliferative effect of neoxanthin and fucoxanthin on cultured cells. Fish. Sci. 2005, 71, 459-461. [CrossRef]

78. Rwigemera, A.; Mamelona, J.; Martin, L.J. Comparative Effects between Fucoxanthinol and its Precursor Fucoxanthin on Viability and Apoptosis of Breast Cancer Cell Lines MCF-7 and MDA-MB-23. Anticancer Res. 2015, 35, 207-219.

79. Ayyad, S.-E.; Basaif, S.; Badria, A.; Ezmirly, S.; Alarif, W.; Badria, F. Antioxidant, cytotoxic, antitumor, and protective DNA damage metabolites from the red sea brown alga Sargassum sp. Pharmacogn. Res. 2011, 3, 160. [CrossRef]

80. Rwigemera, A.; Mamelona, J.; Martin, L.J. Inhibitory effects of fucoxanthinol on the viability of human breast cancer cell lines MCF-7 and MDA-MB-231 are correlated with modulation of the NF-kappaB pathway. Cell Biol. Toxicol. 2014, 30, 157-167. [CrossRef]

81. Ye, G.; Lu, Q.; Zhao, W.; Du, D.; Jin, L.; Liu, Y. Fucoxanthin induces apoptosis in human cervical cancer cell line HeLa via PI3K/Akt pathway. Tumor Biol. 2014, 35, 11261-11267. [CrossRef] 
82. Afzal, S.; Garg, S.; Ishida, Y.; Terao, K.; Kaul, S.; Wadhwa, R. Rat Glioma Cell-Based Functional Characterization of Anti-Stress and Protein Deaggregation Activities in the Marine Carotenoids, Astaxanthin and Fucoxanthin. Mar. Drugs 2019, 17, 189. [CrossRef] [PubMed]

83. Jin, Y.; Qiu, S.; Shao, N.; Zheng, J. Fucoxanthin and Tumor Necrosis Factor-Related Apoptosis-Inducing Ligand (TRAIL) Synergistically Promotes Apoptosis of Human Cervical Cancer Cells by Targeting PI3K/Akt/NF-kB Signaling Pathway. Med. Sci. Monit. 2018, 24, 11-18. [CrossRef] [PubMed]

84. Wu, H.; Fu, X.; Cao, W.; Xiang, W.; Hou, Y.; Ma, J.; Wang, Y.; Fan, C. Induction of Apoptosis in Human Glioma Cells by Fucoxanthin via Triggering of ROS-Mediated Oxidative Damage and Regulation of MAPKs and PI3K-AKT Pathways. J. Agric. Food Chem. 2019, 67, 2212-2219. [CrossRef] [PubMed]

85. Liu, Y.; Zheng, J.; Zhang, Y.; Wang, Z.; Yang, Y.; Bai, M.; Dai, Y. Fucoxanthin Activates Apoptosis via Inhibition of PI3K/Akt/mTOR Pathway and Suppresses Invasion and Migration by Restriction of p38-MMP-2/9 Pathway in Human Glioblastoma Cells. Neurochem. Res. 2016, 41, 2728-2751. [CrossRef]

86. Ganesan, P.; Noda, K.; Manabe, Y.; Ohkubo, T.; Tanaka, Y.; Maoka, T.; Sugawara, T.; Hirata, T. Siphonaxanthin, a marine carotenoid from green algae, effectively induces apoptosis in human leukemia (HL-60) cells. Biochim. Biophys. Acta 2011, 1810, 497-503. [CrossRef]

87. Sugawara, T.; Matsubara, K.; Akagi, R.; Mori, M.; Hirata, T. Antiangiogenic Activity of Brown Algae Fucoxanthin and Its Deacetylated Product, Fucoxanthinol. J. Agric. Food Chem. 2006, 54, 9805-9810. [CrossRef]

88. Wang, J.; Ma, Y.; Yang, J.; Jin, L.; Gao, Z.; Xue, L.; Hou, L.; Sui, L.; Liu, J.; Zou, X. Fucoxanthin inhibits tumour-related lymphangiogenesis and growth of breast cancer. J. Cell. Mol. Med. 2019, 23, 2219-2229. [CrossRef]

89. Nishino, H. Cancer prevention by carotenoids. Mutat. Res. 1998, 402, 159-163. [CrossRef]

90. Okuzumi, J.; Takahashi, T.; Yamane, T.; Kitao, Y.; Inagake, M.; Ohya, K.; Nishino, H.; Tanaka, Y. Inhibitory effects of fucoxanthin, a natural carotenoid, on N-ethyl-N'-nitro-N-nitrosoguanidine-induced mouse duodenal carcinogenesis. Cancer Lett. 1993, 68, 159-168. [CrossRef]

91. Nishino, H. Cancer chemoprevention by natural carotenoids and their related compounds. J. Cell. Biochem. 1995, 59, 231-235. [CrossRef]

92. Terasaki, M.; Iida, T.; Kikuchi, F.; Tamura, K.; Endo, T.; Kuramitsu, Y.; Tanaka, T.; Maeda, H.; Miyashita, K.; Mutoh, M. Fucoxanthin potentiates anoikis in colon mucosa and prevents carcinogenesis in AOM/DSS model mice. J. Nutr. Biochem. 2019, 64, 198-205. [CrossRef] [PubMed]

93. Kim, J. Chemopreventive effects of carotenoids and curcumins on mouse colon carcinogenesis after 1,2-dimethylhydrazine initiation. Carcinogenesis 1998, 19, 81-85. [CrossRef] [PubMed]

94. Wang, J.; Chen, S.; Xu, S.; Yu, X.; Ma, D.; Hu, X.; Cao, X. In vivo induction of apoptosis by fucoxanthin, a marine carotenoid, associated with down-regulating STAT3/EGFR signaling in sarcoma 180 (S180) xenografts-bearing mice. Mar. Drugs 2012, 10, 2055-2068. [CrossRef] [PubMed]

95. Fung, C.; Lock, R.; Gao, S.; Salas, E.; Debnath, J. Induction of autophagy during extracellular matrix detachment promotes cell survival. Mol. Biol. Cell 2008, 19, 797-806. [CrossRef] [PubMed]

96. Reddig, P.J.; Juliano, R.L. Clinging to life: Cell to matrix adhesion and cell survival. Cancer Metastasis Rev. 2005, 24, 425-439. [CrossRef]

97. Kotake-Nara, E.; Terasaki, M.; Nagao, A. Characterization of Apoptosis Induced by Fucoxanthin in Human Promyelocytic Leukemia Cells. Biosci. Biotechnol. Biochem. 2005, 69, 224-227. [CrossRef]

98. Tamura, S.; Narita, T.; Fujii, G.; Miyamoto, S.; Hamoya, T.; Kurokawa, Y.; Takahashi, M.; Miki, K.; Matsuzawa, Y.; Komiya, M.; et al. Inhibition of NF-kappaB transcriptional activity enhances fucoxanthinol-induced apoptosis in colorectal cancer cells. Genes Environ. 2019, 41, 1. [CrossRef]

99. Terasaki, M.; Maeda, H.; Miyashita, K.; Mutoh, M. Induction of Anoikis in Human Colorectal Cancer Cells by Fucoxanthinol. Nutr. Cancer 2017, 69, 1043-1052. [CrossRef]

100. Taira, J.; Sonamoto, M.; Uehara, M. Dual Biological Functions of a Cytoprotective Effect and Apoptosis Induction by Bioavailable Marine Carotenoid Fucoxanthinol through Modulation of the Nrf2 Activation in RAW264.7 Macrophage Cells. Mar. Drugs 2017, 15, 305. [CrossRef]

101. Tomicic, M.T.; Kaina, B. Topoisomerase degradation, DSB repair, p53 and IAPs in cancer cell resistance to camptothecin-like topoisomerase I inhibitors. Biochim. Biophys. Acta BBA Rev. Cancer 2013, 1835, 11-27. [CrossRef] 
102. Lin, T.-Y.; Chan, H.-H.; Chen, S.-H.; Sarvagalla, S.; Chen, P.-S.; Coumar, M.S.; Cheng, S.M.; Chang, Y.-C.; Lin, C.-H.; Leung, E.; et al. BIRC5/Survivin is a novel ATG12-ATG5 conjugate interactor and an autophagyinduced DNA damage suppressor in human cancer and mouse embryonic fibroblast cells. Autophagy 2020, 16, 1296-1313. [CrossRef] [PubMed]

103. Massagué, J.; Obenauf, A.C. Metastatic colonization by circulating tumour cells. Nature 2016, 529, $298-306$. [CrossRef] [PubMed]

104. Hanahan, D.; Weinberg, R.A. Hallmarks of cancer: The next generation. Cell 2011, 144, 646-674. [CrossRef] [PubMed]

105. Chen, J.; Wang, M.; Xiang, Y.; Ru, X.; Ren, Y.; Liu, X.; Qiu, L.; Zhang, Y. Nrf1 Is Endowed with a Dominant Tumor-Repressing Effect onto the Wnt/ $\beta$-Catenin-Dependent and Wnt/ $\beta$-Catenin-Independent Signaling Networks in the Human Liver Cancer. Oxid. Med. Cell. Longev. 2020, 2020, 5138539. [CrossRef] [PubMed]

106. Lamouille, S.; Xu, J.; Derynck, R. Molecular mechanisms of epithelial-mesenchymal transition. Nat. Rev. Mol. Cell Biol. 2014, 15, 178-196. [CrossRef] [PubMed]

107. Li, C.-J.; Chu, P.-Y.; Yiang, G.-T.; Wu, M.-Y. The Molecular Mechanism of Epithelial-Mesenchymal Transition for Breast Carcinogenesis. Biomolecules 2019, 9, 476. [CrossRef] [PubMed]

108. Folkman, J.; Shing, Y. Angiogenesis. J. Biol. Chem. 1992, 267, 10931-10934. [PubMed]

109. Folkman, J.; Klagsbrun, M. Angiogenic factors. Science 1987, 235, 442-447. [CrossRef]

110. Tonini, T.; Rossi, F.; Claudio, P.P. Molecular basis of angiogenesis and cancer. Oncogene 2003, 22, 6549-6556. [CrossRef]

111. Torisu, H.; Ono, M.; Kiryu, H.; Furue, M.; Ohmoto, Y.; Nakayama, J.; Nishioka, Y.; Sone, S.; Kuwano, M. Macrophage infiltration correlates with tumor stage and angiogenesis in human malignant melanoma: Possible involvement of TNFalpha and IL-1alpha. Int. J. Cancer 2000, 85, 182-188. [CrossRef]

112. Coussens, L.M.; Raymond, W.W.; Bergers, G.; Laig-Webster, M.; Behrendtsen, O.; Werb, Z.; Caughey, G.H.; Hanahan, D. Inflammatory mast cells up-regulate angiogenesis during squamous epithelial carcinogenesis. Genes Dev. 1999, 13, 1382-1397. [CrossRef] [PubMed]

113. Coussens, L.M.; Tinkle, C.L.; Hanahan, D.; Werb, Z. MMP-9 Supplied by Bone Marrow-Derived Cells Contributes to Skin Carcinogenesis. Cell 2000, 103, 481-490. [CrossRef]

114. Greten, F.R.; Eckmann, L.; Greten, T.F.; Park, J.M.; Li, Z.-W.; Egan, L.J.; Kagnoff, M.F.; Karin, M. IKKbeta links inflammation and tumorigenesis in a mouse model of colitis-associated cancer. Cell 2004, 118, 285-296. [CrossRef] [PubMed]

115. Hudson, J.D.; Shoaibi, M.A.; Maestro, R.; Carnero, A.; Hannon, G.J.; Beach, D.H. A proinflammatory cytokine inhibits p53 tumor suppressor activity. J. Exp. Med. 1999, 190, 1375-1382. [CrossRef]

116. Martins-Green, M.; Boudreau, N.; Bissell, M.J. Inflammation is responsible for the development of wound-induced tumors in chickens infected with Rous sarcoma virus. Cancer Res. 1994, 54, 4334-4341.

117. Müller, A.; Homey, B.; Soto, H.; Ge, N.; Catron, D.; Buchanan, M.E.; McClanahan, T.; Murphy, E.; Yuan, W.; Wagner, S.N.; et al. Involvement of chemokine receptors in breast cancer metastasis. Nature 2001, 410, 50-56. [CrossRef]

118. Giavazzi, R.; Garofalo, A.; Bani, M.R.; Abbate, M.; Ghezzi, P.; Boraschi, D.; Mantovani, A.; Dejana, E. Interleukin 1-induced augmentation of experimental metastases from a human melanoma in nude mice. Cancer Res. 1990, 50, 4771-4775.

119. Singh, N.; Baby, D.; Rajguru, J.P.; Patil, P.B.; Thakkannavar, S.S.; Pujari, V.B. Inflammation and cancer. Ann. Afr. Med. 2019, 18, 121-126. [CrossRef]

120. Arulselvan, P.; Fard, M.T.; Tan, W.S.; Gothai, S.; Fakurazi, S.; Norhaizan, M.E.; Kumar, S.S. Role of Antioxidants and Natural Products in Inflammation. Oxid. Med. Cell. Longev. 2016, 2016, 5276130. [CrossRef]

121. Vijay, K.; Sowmya, P.R.-R.; Arathi, B.P.; Shilpa, S.; Shwetha, H.J.; Raju, M.; Baskaran, V.; Lakshminarayana, R. Low-dose doxorubicin with carotenoids selectively alters redox status and upregulates oxidative stress-mediated apoptosis in breast cancer cells. Food Chem. Toxicol. Int. J. Publ. Br. Ind. Biol. Res. Assoc. 2018, 118, 675-690. [CrossRef]

122. Shin, J.; Song, M.-H.; Oh, J.-W.; Keum, Y.-S.; Saini, R.K. Pro-oxidant Actions of Carotenoids in Triggering Apoptosis of Cancer Cells: A Review of Emerging Evidence. Antioxidants 2020, 9, 532. [CrossRef]

123. Lin, H.-W.; Chen, Y.-C.; Liu, C.-W.; Yang, D.-J.; Chen, S.-Y.; Chang, T.-J.; Chang, Y.-Y. Regulation of virus-induced inflammatory response by Dunaliella salina alga extract in macrophages. Food Chem. Toxicol. 2014, 71, 159-165. [CrossRef] [PubMed] 
124. Rosa, G.P.; Tavares, W.R.; Sousa, P.M.C.; Pagès, A.K.; Seca, A.M.L.; Pinto, D.C.G.A. Seaweed Secondary Metabolites with Beneficial Health Effects: An Overview of Successes in In Vivo Studies and Clinical Trials. Mar. Drugs 2019, 18, 8. [CrossRef] [PubMed]

125. Asai, A.; Yonekura, L.; Nagao, A. Low bioavailability of dietary epoxyxanthophylls in humans. Br. J. Nutr. 2008, 100, 273-277. [CrossRef] [PubMed]

126. Abidov, M.; Ramazanov, Z.; Seifulla, R.; Grachev, S. The effects of Xanthigen ${ }^{\mathrm{TM}}$ in the weight management of obese premenopausal women with non-alcoholic fatty liver disease and normal liver fat. Diabetes Obes. Metab. 2010, 12, 72-81. [CrossRef] [PubMed]

127. Hashimoto, T.; Ozaki, Y.; Mizuno, M.; Yoshida, M.; Nishitani, Y.; Azuma, T.; Komoto, A.; Maoka, T.; Tanino, Y.; Kanazawa, K. Pharmacokinetics of fucoxanthinol in human plasma after the oral administration of kombu extract. Br. J. Nutr. 2012, 107, 1566-1569. [CrossRef] [PubMed]

128. Mikami, N.; Hosokawa, M.; Miyashita, K.; Sohma, H.; Ito, Y.M.; Kokai, Y. Reduction of HbA1c levels by fucoxanthin-enriched akamoku oil possibly involves the thrifty allele of uncoupling protein 1 (UCP1): A randomised controlled trial in normal-weight and obese Japanese adults. J. Nutr. Sci. 2017, 6, e5. [CrossRef]

129. Ren, R.; Azuma, Y.; Ojima, T.; Hashimoto, T.; Mizuno, M.; Nishitani, Y.; Yoshida, M.; Azuma, T.; Kanazawa, K. Modulation of platelet aggregation-related eicosanoid production by dietary F-fucoidan from brown alga Laminaria japonica in human subjects. Br. J. Nutr. 2013, 110, 880-890. [CrossRef]

130. Hitoe, S.; Shimoda, H. Seaweed Fucoxanthin Supplementation Improves Obesity Parameters in Mild Obese Japanese Subjects. Funct. Foods Health Dis. 2017, 7, 246. [CrossRef]

131. ClinicalTrials.gov is a Database of Privately and Publicly Funded Clinical Studies Conducted Around the World. It is a resource provided by the United States National Library of Medicine. Available online: https://clinicaltrials.gov/ (accessed on 21 July 2020) (updated on 23 October 2020).

132. Hanahan, D.; Weinberg, R.A. The hallmarks of cancer. Cell 2000, 100, 57-70. [CrossRef]

133. Ferreira, S.; Dutreix, M. DNA repair inhibitors to enhance radiotherapy: Progresses and limitations. Cancer Radiother. J. Soc. Francaise Radiother. Oncol. 2019, 23, 883-890. [CrossRef] [PubMed]

134. Rocha, C.R.R.; Silva, M.M.; Quinet, A.; Cabral-Neto, J.B.; Menck, C.F.M. DNA repair pathways and cisplatin resistance: An intimate relationship. Clin. Sao Paulo Braz. 2018, 73, e478s. [CrossRef] [PubMed]

135. Liberti, M.V.; Locasale, J.W. The Warburg Effect: How Does it Benefit Cancer Cells? Trends Biochem. Sci. 2016, 41, 211-218. [CrossRef]

136. Rosen, R.; Vagaggini, T.; Chen, Y.; Hu, D.-N. Zeaxanthin inhibits hypoxia-induced VEGF secretion by RPE cells through decreased protein levels of hypoxia-inducible factors-1 $\alpha$. BioMed Res. Int. 2015, 2015, 687386. [CrossRef] [PubMed]

137. Zhao, D.; Kwon, S.-H.; Chun, Y.S.; Gu, M.-Y.; Yang, H.O. Anti-Neuroinflammatory Effects of Fucoxanthin via Inhibition of Akt/NF-kB and MAPKs/AP-1 Pathways and Activation of PKA/CREB Pathway in Lipopolysaccharide-Activated BV-2 Microglial Cells. Neurochem. Res. 2017, 42, 667-677. [CrossRef]

138. Coussens, L.M.; Zitvogel, L.; Palucka, A.K. Neutralizing tumor-promoting chronic inflammation: A magic bullet? Science 2013, 339, 286-291. [CrossRef]

139. Ye, G.-L.; Du, D.-L.; Jin, L.-J.; Wang, L.-L. Sensitization of TRAIL-resistant cervical cancer cells through combination of TRAIL and fucoxanthin treatments. Eur. Rev. Med. Pharmacol. Sci. 2017, 21, 5594-5601. [CrossRef]

140. Eid, S.Y.; El-Readi, M.Z.; Wink, M. Carotenoids reverse multidrug resistance in cancer cells by interfering with ABC-transporters. Phytomedicine 2012, 19, 977-987. [CrossRef]

Publisher's Note: MDPI stays neutral with regard to jurisdictional claims in published maps and institutional affiliations.

(C) 2020 by the authors. Licensee MDPI, Basel, Switzerland. This article is an open access article distributed under the terms and conditions of the Creative Commons Attribution (CC BY) license (http://creativecommons.org/licenses/by/4.0/). 